\title{
The Interplay between Dividends and Leverage inside Commercial Banks
}

\author{
Silvia Bressan ${ }^{1}$ \\ ${ }^{1}$ MODUL University Vienna, Vienna, Austria \\ Correspondence: Silvia Bressan, MODUL University Vienna, Am Kahlenberg 1, 1190 Vienna, Austria.
}

Received: January 6, 2017

Accepted: January 17, 2017

Online Published: February 28, 2017

doi:10.5430/ijfr.v8n2p7

URL: http://dx.doi.org/10.5430/ijfr.v8n2p7

\begin{abstract}
The paper analyzes the dividends paid by a large sample of commercial banks in the United States during 2006-2011. The most interesting findings arise after the end of 2008. Our measures for the probability of paying dividends and for the dividend payout ratio are positively related to the banks' non-deposit leverage. Conversely, banks' dividends correlate negatively to deposit leverage. We argue that during the crisis of 2007-2009 the liquidity needs of banks resorted more to deposits, than to non-deposit debt. This, in turn, had an impact on banks' dividend policies, to the extent that firms which could raise deposits preferred to preserve their financial stability, and did not pay huge dividends.
\end{abstract}

Keywords: banks, dividends, leverage

\section{Introduction}

The dividend policy of banks during the recent crisis of 2007-2009 is a controversial issue. Acharya et al. (2012) show that during the crisis banks continued to pay out large dividends, despite huge credit losses depleting their equity and highly levered capital structures. When losses can be anticipated, paying dividends to equityholders can be seen as an "extraction" (or, "expropriation") of value from debtholders. Acharya et al. (2012) affirm that the high dividends paid by banks during the turmoil revealed some risk shifting (or, asset substitution) on creditors.

Several papers claim that by paying out earnings firms exacerbate moral hazard, and shareholders might leave debtholders with an "empty shell” (Black (1976), Myers (1977), Smith and Warner (1979), Easterbrook (1984), and Leuz, Deller, and Stubenrath (1998), Akerlof and Romer (1993), Haq and Heaney (2012), and Kanas (2013)).

Inspired by the discussion in Acharya et al. (2012), this paper examines in more depth the empirical relationship between leverage and dividends inside banks. The previous research has more frequently treated the nexus debt-dividends inside non-financial firms than inside financial firms. There is not sound knowledge on the payout policies in the banking sector, and we believe this paper contributes to a better understanding of this subject.

We examine a large sample of United States commercial banks during 2000-2011. One interesting feature of our approach is to separate the effect on dividends from deposit leverage (retail funding) versus the effect from non-deposit leverage (wholesale funding). (Note 1) Thus, we exploit the layered composition of the debt structure of commercial banks in order to obtain insights on their dividend policies.

We discover that dividends are significantly affected by leverage only after October 2008, namely when banks were experiencing the most critical phases of the crisis. The impact from leverage is heterogeneous. Our measures for the probability of paying dividends and for the dividend payout ratio are positively related to non-deposit leverage, while are negatively correlated to deposit leverage.

We explain this pattern in light of the changes brought by the crisis on banks' financing. In the United States banks were observed raising equity capital and replacing with deposits other secured and unsecured wholesale debt securities (Oura et al. (2013)). At the same time, the crisis has affected the behavior of depositors, given that depositors started to perceive that their funds were put at risk, despite the presence of deposit insurance schemes (Mora (2010)). There was a high amount of deposits above the deposit insurance limit, and the FDIC fund fell dramatically by August 2009. Depositors were no longer net suppliers of liquidity, and firms were active in soliciting deposits (Acharya and Mora (2012)). 
We argue that our outcomes may reveal the troubles in fund-raising which banks had to face during and after the crisis. Given the difficulties in obtaining interbank credit, the companies which could restore their liquidity by increasing deposits didn't want to pay out huge dividends. The same effect does not hold for the non-deposit debt. The companies increasing non-deposit debt had also more generous dividend policies.

The set of empirical methods employed in the analysis is broad, and helps to support the robustness of the outcomes' interpretation. Besides performing ordinary least squares (OLS) and instrumental variables (IV) regressions, we show outputs where the dividend payout is estimated following, alternatively, the method of Arellano and Bond (1991) for dynamic panel data (DPD), simultaneous systems of equations, and the approach of Honore (1992) for censored normal regression (Tobit) models with fixed effects.

Lastly, in order to characterize the total payout policy of our firms, we show results on shares repurchases. In general, we do not notice a strong linkage between banks' shares repurchases and the composition of leverage.

The paper is organized as follows. In Section 2 we overview the academic research on dividends inside financial firms. Section 3 analyzes a large panel of United States commercial banks. We use econometric techniques which relate banks' dividend policies to leverage. We distinguish between deposit and non-deposit leverage, and separate the sub-sample of relative stability (before 2006) from the period of financial turmoil (after Summer 2007). Section 4 and Section 5 perform additional tests in order to verify the plausibility of the interpretation. Section 6 implements econometric methods which integrate the baseline set of outcomes. Section 7 explores decisions on share repurchases. Section 8 concludes the paper.

\section{Related Literature}

This paper studies the dividend policies of banks, on which little is known. Dickens, Casey, and Newman (2002) and Kleff and Weber (2010) find that the dividend policies of financial firms depend on their size, risk, and profitability. Casey and Dickens (2000) study the effects on banks' dividends from tax changes. Basse et al. (2014) and Boldin and Legget (1995) verify to what extent dividends may signal the quality of banks. Eriotis, Vasiliou, and Zisis (2007) describe the dividends of Greek banks during 1997-2001. Hirtle (1998) shows that in 1997 United States banks pay huge dividends as a consequence of high earnings retained from the past years.

Our paper contributes to this topic, and examines how commercial banks pay dividends in relation to the composition of their debt. Two previous studies mention the interplay between dividends and debt inside banks. Gropp and Heider (2010) survey international banks during 1991-2004, and find that banks which pay dividends have lower market and book leverage. Conversely, Octavia and Brown (2010) show that during 1996-2005 banks from developing countries which pay dividends have larger leverage.

In the final part of the paper we analyze share repurchases. We refer to Grullon and Ikenberry (2000) and Allen and Michaely (2003) for a review on the share repurchases inside non-financial firms. The empirical evidence on the share repurchases of banks is scarce. One example is Hirtle (2004), who shows that the repurchase of stocks improves the performance of bank holding companies.

\section{Empirical Analysis}

\subsection{Data}

Our data source is SNL Financial LC. (Note 2) We collect data on all the United States publicly listed institutions classified as operating "bank," which SNL Financial defines as "a company whose primary business is to accept deposits and make loans." (Note 3) Observations go from 2000q1 until 2011q3, and in total we have 46,107 bank-quarter observations. The following three sub-sections describe the main variables employed in the analysis of the paper. Table 1 reports the variables' most important descriptive statistics.

Table 1. Variables for banks'́ dividends, leverage, and control variables

\begin{tabular}{ccccccccc}
\hline Variable & $\begin{array}{c}\text { N (as of } \\
\mathbf{2 0 1 1 q 3})\end{array}$ & Mean & Median & $\mathbf{5 \%}$ & $\mathbf{2 5 \%}$ & $\mathbf{7 5 \%}$ & $\mathbf{9 5 \%}$ & Std. Dev \\
\hline Dividend Policy & & & & & & & & \\
DIVIDEND_DUMMY (\%) & 981 & 64.859 & 100 & 0.000 & 0.000 & 100 & 100 & 0.477 \\
DIVIDEND_EARNINGS (\%) & 981 & 35.286 & 28.000 & 0.000 & 0.000 & 47.630 & 102.170 & 55.049 \\
DIVIDEND_EQUITY $(\%)$ & 981 & 2.869 & 2.120 & 0.000 & 0.000 & 4.840 & 8.830 & 3.563
\end{tabular}




\begin{tabular}{ccccccccc} 
Leverage & & & & & & & & \\
DEP\&NONDEP_TA (\%) & 981 & 88.297 & 89.569 & 80.309 & 87.550 & 91.044 & 93.071 & 6.379 \\
DEPOSITS_TA (\%) & 981 & 78.928 & 80.980 & 62.340 & 74.690 & 85.470 & 89.820 & 9.685 \\
NONDEPOSITS_TA (\%) & 981 & 9.365 & 7.870 & 0.000 & 2.790 & 13.880 & 24.530 & 8.381 \\
NONDEPOSITS_TL (\%) & 981 & 10.522 & 8.798 & 0.000 & 3.148 & 15.502 & 27.438 & 9.540 \\
SHORTTERM_NONDEP_TA (\%) & 981 & 0.841 & 0.000 & 0.000 & 0.000 & 0.378 & 4.971 & 2.304 \\
REPOS_TA (\%) & 981 & 2.479 & 0.923 & 0.000 & 0.000 & 3.479 & 9.648 & 4.188 \\
Control Variables & & & & & & & & \\
SIZE (log of Assets) & 981 & 13.174 & 12.912 & 11.096 & 12.148 & 13.866 & 18.756 & 1.610 \\
ROA (\%) & 981 & 0.430 & 0.830 & -2.220 & 0.370 & 1.170 & 1.690 & 2.295 \\
MTBV (\%) & 981 & 139.801 & 131.100 & 43.500 & 90.400 & 176.900 & 266.200 & 70.970 \\
EQUITY_TA (\%) & 981 & 10.457 & 9.340 & 6.030 & 7.930 & 11.190 & 17.620 & 5.935 \\
CASH_TA (\%) & 981 & 7.743 & 5.421 & 1.808 & 3.270 & 9.383 & 20.756 & 7.738 \\
LOANS_TA (\%) & 981 & 66.144 & 67.945 & 41.880 & 59.740 & 74.870 & 83.440 & 12.840 \\
RWA_TA (\%) & 981 & 72.084 & 72.730 & 52.100 & 64.650 & 80.150 & 90.220 & 11.864 \\
INCOME_TAX_TA (\%) & 981 & 0.086 & 0.057 & 0.000 & 0.000 & 0.142 & 0.299 & 0.181 \\
EMPL_COMP & 981 & 61.550 & 56.315 & 37.310 & 47.020 & 70.190 & 103.23 & 22.169 \\
CAPRATIO $(\%)$ & 981 & 16.497 & 13.960 & 10.540 & 12.150 & 16.890 & 28.130 & 13.124 \\
\hline
\end{tabular}

The table reports the average value of the variables during the sample period 2000q1-2011q3. DIVIDEND_EARNINGS and DIVIDEND_EQUITY are calculated on the banks with positive earnings and positive equity, respectively.

\subsection{Variables for Dividends}

We approximate the bank's decision on dividends constructing the following three variables: (i) DIVIDEND_DUMMY is a dummy variable assuming value one if the firm has reported a positive dividend during the year-quarter, while assuming value zero if the reported dividend is zero; (ii) DIVIDEND_EARNINGS is the dividend payout ratio, calculated as dividends per share in percentage to earnings per share at the end of the quarter; (iii) as a second measure of payout, DIVIDEND_EQUITY measures the dividends per share in percentage to the common equity per share at the end of the quarter. The variable (ii) is the same dividend payout ratio employed by Rozeff (1982), and Braggion and Moore (2010), while as a reference for the variable in (iii), we refer to Onali (2012), who argues that DIVIDEND_EQUITY is a more reliable payout measure for banks, given the importance of equity capital in banking. (Note 4)

Table 3 shows dividends along the sample period, and for every year it reports the percentage of dividend paying banks together with the associated average payout ratio. Until 2008 the share of dividend paying banks is above $65 \%$. During 2010-2011 instead, the number goes below 55\%. Note in 2009 the peak in DIVIDEND_EARNINGS, when half of the banks' earnings was paid out through dividends. DIVIDEND_EQUITY is instead more stable and decreases progressively.

Table 3. Variables for banks' dividends during the years of the sample

\begin{tabular}{cccccc}
\hline & \multicolumn{3}{c}{ All sample } & & \multicolumn{2}{c}{ Dividend paying banks } \\
YIIVIDEND_DUMMY=1) \\
& DIVIDEND_DU & DIVIDEND_EARNI & DIVIDEND_EQ & DIVIDEND_EAR & DIVIDEND_E \\
& MMY & NGS & UITY & NINGS & QUITY \\
& $(\%)$ & $(\%)$ & $(\%)$ & $(\%)$ & $(\%)$ \\
\hline 2000 (Q1-Q4) & 77.25 & 35.795 & 4.015 & 46.338 & 5.406 \\
2001 (Q1-Q4) & 74.01 & 35.498 & 3.760 & 47.962 & 5.276 \\
2002 (Q1-Q4) & 69.37 & 31.491 & 3.556 & 45.399 & 5.191 \\
$2003(\mathrm{Q} 1-\mathrm{Q} 4)$ & 67.35 & 32.316 & 3.508 & 47.979 & 5.283
\end{tabular}




\begin{tabular}{|c|c|c|c|c|c|}
\hline 2004 (Q1-Q4) & 65.79 & 33.364 & 3.457 & 50.714 & 5.358 \\
\hline 2005 (Q1-Q4) & 66.69 & 31.768 & 3.403 & 47.635 & 5.320 \\
\hline 2006 (Q1-Q4) & 65.19 & 33.672 & 3.254 & 51.653 & 5.275 \\
\hline 2007 (Q1-Q4) & 65.63 & 37.930 & 3.157 & 57.790 & 5.229 \\
\hline 2008 (Q1-Q4) & 65.06 & 47.366 & 2.765 & 72.802 & 5.104 \\
\hline 2009 (Q1-Q4) & 62.24 & 50.539 & 1.877 & 81.207 & 4.338 \\
\hline 2010 (Q1-Q4) & 54.21 & 30.630 & 1.566 & 56.502 & 3.829 \\
\hline 2011 (Q1-Q3) & 50.34 & 22.744 & 1.420 & 45.179 & 3.399 \\
\hline
\end{tabular}

\subsection{Variables for Leverage}

Our approach is to decompose the leverage structure of the banks. The total leverage is calculated as the sum of deposits and non-deposits normalized by total assets (DEP\&NONDEP_TA). We then separate the deposit leverage from the non-deposit leverage, and DEPOSITS_TA and NONDEPOSITS_TA divide respectively deposits and non-deposits by total assets. We further compute the ratio of non-deposits over the total amount of deposit plus non-deposit liabilities (NONDEPOSITS_TL), where liabilities are defined as the difference between the balance sheet assets and equity capital.

Table 1 shows that commercial banks are funding $79 \%$ of their assets via deposits, while only the $9 \%$ of assets are funded via non-deposits. Table 2 concentrates on the dividend paying banks, namely the banks that pay non-zero dividends to shareholders. The dividend paying banks have got non-deposit leverage equal to $11.3 \%$, namely above the average value on the sample. The same firms have distributed to owners more than the half of their profits, given that DIVIDEND_EARNINGS is $54.4 \%$.

Table 2. Variables for dividends and leverage for the banks paying dividends

\begin{tabular}{|c|c|c|c|c|c|c|c|c|}
\hline \multirow[b]{2}{*}{ Variable } & \multicolumn{8}{|c|}{ Dividend paying banks (DIVIDEND_DUMMY=1) } \\
\hline & $\begin{array}{c}\mathrm{N}(\text { as of } \\
2011 Q 3)\end{array}$ & Mean & Median & $5 \%$ & $25 \%$ & $75 \%$ & $95 \%$ & $\begin{array}{l}\text { Std. } \\
\text { Dev }\end{array}$ \\
\hline \multicolumn{9}{|l|}{ Dividend Policy } \\
\hline DIVIDEND_EARNINGS (\%) & 284 & 54.404 & 41.500 & 13.790 & 29.270 & 58.820 & 127.030 & 60.267 \\
\hline DIVIDEND_EQUITY $(\%)$ & 284 & 4.990 & 4.470 & 1.260 & 3.060 & 6.200 & 10.140 & 3.376 \\
\hline \multicolumn{9}{|l|}{ Leverage } \\
\hline DEP\&NONDEP_TA $(\%)$ & 284 & 88.992 & 89.608 & 84.403 & 87.960 & 90.886 & 92.585 & 4.014 \\
\hline DEPOSITS_TA $(\%)$ & 284 & 77.656 & 79.260 & 61.680 & 73.090 & 84.160 & 88.910 & 9.256 \\
\hline NONDEPOSITS_TA $(\%)$ & 284 & 11.318 & 10.090 & 0.130 & 5.030 & 15.920 & 26.350 & 8.429 \\
\hline NONDEPOSITS_TL (\%) & 284 & 12.729 & 11.302 & 0.171 & 5.651 & 17.877 & 29.547 & 9.579 \\
\hline
\end{tabular}

The table reports the average value of the variables during the sample period 2000q1-2011q3. DIVIDEND_EARNINGS and DIVIDEND_EQUITY are calculated on the banks with positive earnings and positive equity, respectively. 
Figure 1 plots deposit leverage along the time-line. From the end of 2008, the banks of the sample have collected a larger share of deposits. The figure displays how the dividend paying banks have almost always lower values of deposits.

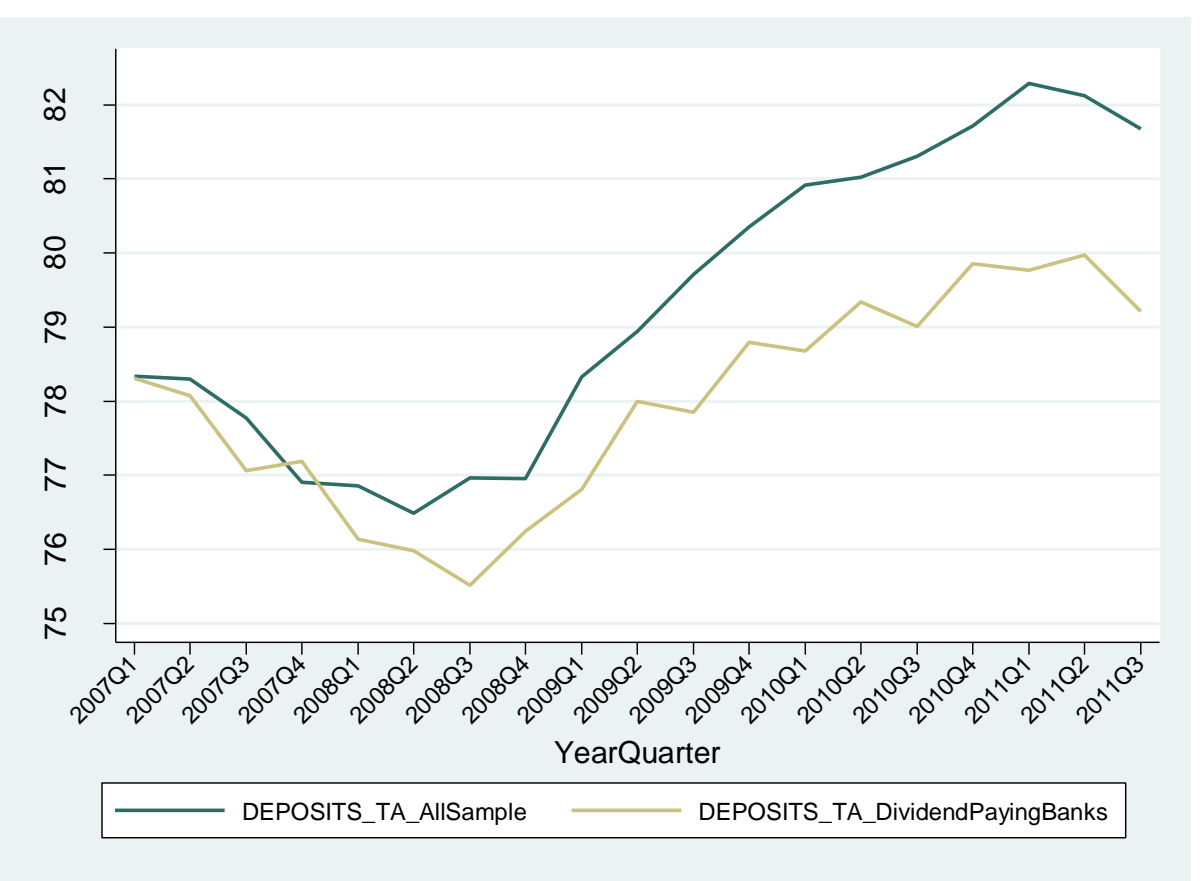

Figure 1. Deposit leverage during quarters

The figure shows the variable DEPOSITS_TA during 2007q1-2011q3 for the entire sample and for the dividend paying banks.

Finally, in Table 4 we calculate the pair-wise correlation between the set of variables for dividends and for leverage. In general, dividends are positively correlated with non-deposit leverage, while negatively correlated to deposit leverage. In absolute terms, the correlation coefficient goes never above 0.223 (which is the correlation between DIVIDEND_DUMMY and NONDEPOSITS_TA).

Table 4. Pair-wise correlation between the variables for dividends and the variables for leverage

\begin{tabular}{|c|c|c|c|c|c|c|}
\hline $\begin{array}{l}\text { Pair-wise } \\
\text { correlation }\end{array}$ & $\begin{array}{c}\text { DIVIDEND_D } \\
\text { UMMY }\end{array}$ & $\begin{array}{c}\text { DIVIDEND_EA } \\
\text { RNINGS } \\
\end{array}$ & $\begin{array}{c}\text { DIVIDEND_E } \\
\text { QUITY } \\
\end{array}$ & $\begin{array}{c}D E P \& N O N D E \\
P \_T A\end{array}$ & $\begin{array}{c}\text { NONDEPOSIT } \\
\text { S_TA }\end{array}$ & DEPOSITS_TA \\
\hline $\begin{array}{c}\text { DIVIDEND_D } \\
\text { UMMY }\end{array}$ & 1.000 & & & & & \\
\hline $\begin{array}{c}\text { DIVIDEND_EA } \\
\text { RNINGS }\end{array}$ & 0.472 & 1.000 & & & & \\
\hline $\begin{array}{c}\text { DIVIDEND_E } \\
\text { QUITY }\end{array}$ & 0.656 & 0.582 & 1.000 & & & \\
\hline $\begin{array}{c}D E P \& N O N D E \\
P \_T A\end{array}$ & -0.002 & -0.023 & 0.055 & 1.000 & & \\
\hline $\begin{array}{c}\text { NONDEPOSIT } \\
\text { S_TA }\end{array}$ & 0.223 & 0.102 & 0.190 & 0.166 & 1.000 & \\
\hline DEPOSITS_TA & -0.209 & -0.105 & -0.143 & 0.517 & -0.759 & 1.000 \\
\hline
\end{tabular}

The table reports the pair-wise correlation between the variables for dividends and the variables for leverage. The sample period is $2000 \mathrm{q} 1-2011 \mathrm{q} 3 .{ }^{*} \mathrm{p}<0.10,{ }^{* *} \mathrm{p}<0.05,{ }^{* * *} \mathrm{p}<0.01$ 


\subsection{Additional Control Variables}

Our regressions include a large set of control variables which take into account of the most important corporate features contributing to the determination of dividends. We measure the size of the company through the natural logarithm of total assets (SIZE), while profitability is captured by the return on assets (ROA). The market-to-book-ratio $(M T B V)$ approximates investment opportunities. Other items in the banks's balance sheet that we include in the set of covariates are: equity, (EQUITY_TA), cash (CASH_TA), loans, (LOANS_TA), risk-weighted assets $\left(R W A \_T A\right)$, and income taxes (INCOME_TAX_TA). All the previous variables are normalized by total assets. We also have one control for the employees' compensation, and the index EMPL_COMP is the ratio of the employees' compensation and benefits over the average full-time equivalent employees. Finally, the regulatory capital requirement is taken into consideration through the risk adjusted total capital ratio, namely the sum of tier 1 and tier 2 capital over risk-weighted assets (CAPRATIO). The mean capital ratio is $16.497 \%$, hence above the minimum required capital ratio of $10 \%$ established under the Basel II agreement. Among others, Berger et al. (2008) comment how banks tend to hold capital buffers highly above the regulatory minimum.

\subsection{Empirical Strategy}

Using different regression models, we estimate the effect on the three variables for dividends from the variables for leverage, plus the additional controls. The specification for DIVIDEND_DUMMY is the following logit model in (1):

$$
\begin{aligned}
\text { Prob(DIVIDEND_DUMMY } & =1) \\
& =F\left(\alpha_{1} \text { LEVERAGE }_{d, i, t}+\alpha_{2} \text { SIZE }_{i, t}+\alpha_{3} \text { ROA }_{i, t}+\alpha_{4} E_{\text {EUITY_T }} A_{i, t}+\alpha_{5} \text { CASH_T }_{i, t}\right. \\
& +\alpha_{6} \text { MTBV }_{i, t}+\alpha_{7} \text { LOANS_T }_{i, t}+\alpha_{8} R W A_{-} T A_{i, t}+\alpha_{9} \text { INCOME_TAX_T }_{i, t}+\alpha_{10} E M P L_{-} C O M P_{i, t} \\
& \left.+\alpha_{11} \text { CAPRATIO }_{i, t}+\sum_{i} \text { bank }_{i}+\sum_{t} \text { quarter }_{t}+\varepsilon_{i, t}\right)
\end{aligned}
$$

Where $d=$ DEP\&NONDEP_TA,NONDEPOSITS_TA,DEPOSITS_TA,NONDEPOSITS_TL

We are pooling data over time and across firms, and include quarter and bank fixed effects. Standard errors are clustered at the bank level, since observations might be correlated across time. The logit model allows interpreting the coefficients estimated on the regressors as the impact from the associated variables on the probability that the bank is paying dividends. We run four versions of equation (1) which differ only in the variable for the bank leverage. Given that the negative correlation between NONDEPOSITS_TA and DEPOSITS_TA is quite high, we run a separated specification for each leverage variable in order to avoid that potential multicollinearity spoils severely the results. The outcomes are reported in Panel A of Table 5.

For the two variables measuring the relative dividend payout instead, we estimate the following generalized partial adjustment model in (2):

$$
\begin{aligned}
\text { DIVIDEND_PAYOUT }_{p, i, t} & \\
& =\alpha_{0}+\alpha_{1} \text { DIVIDEND_PAYOUT }_{p, i,(t-1)}+\alpha_{2} \text { LEVERAGE }_{d, i, t}+\alpha_{3} \text { SIZ }_{i, t}+\alpha_{4} R O A_{i, t} \\
& +\alpha_{5} \text { EQUITY_TA }_{i, t}+\alpha_{6} \text { CASH_T }_{i, t}+\alpha_{7} M T B V_{i, t}+\alpha_{8} L O A N S_{-} T A_{i, t}+\alpha_{9} R W A_{-} T A_{i, t} \\
& +\alpha_{10} \text { INCOME_TAX_T }_{i, t}+\alpha_{11} E M P L_{-} C O M P_{i, t}+\alpha_{12} \text { CAPRATIO }_{i, t}+\sum_{i} \text { bank }_{i} \\
& +\sum_{t} \text { quarter }_{t}+\varepsilon_{i, t}
\end{aligned}
$$

where $p=$ DIVIDEND_EARNINGS,DIVIDEND_EQUITY

where $d=D E P \& N O N D E P \_T A, N O N D E P O S I T S_{-} T A, D E P O S I T S_{-} T A, N O N D E P O S I T S_{-} T L$

The set of covariates stays the same as in equation (1); time and bank fixed effects are included, and standard errors are clustered at the firm level. The Panels B-C of Table 5 display results. 
Both model (1) and model (2) are estimated across three sub-periods. The first sub-period goes from 2000q1 until $2007 \mathrm{q} 3$, and we consider this time frame as a period of relative stability. The second sub-period extends from $2007 q 4$ until 2008q4, namely after the first signs of disorder due to the collapse of the subprime mortgages market, until the failure of Lehman Brothers in September 2008. Finally, the third sub-period spans from 2008q3 until 2011q3, namely from the peak of the crisis during fall 2008, until the return to more quiet conditions. During this latter period, some big investment banks were re-organized, and the United States Government decided to intervene through provisions, as the Troubled Asset Relief Program (TARP). All the Panels of Table 5 separate the estimates across the three sub-periods.

Table 5. The effect from leverage on banks' dividends during three time horizons

\begin{tabular}{|c|c|c|c|c|c|c|c|c|c|c|c|c|}
\hline \multirow{3}{*}{ Panel A } & \multicolumn{12}{|c|}{ DIVIDEND_DUMMY } \\
\hline & \multicolumn{4}{|c|}{$2000 Q 1-2007 Q 3$} & \multicolumn{4}{|c|}{$2007 Q 4-2008 Q 3$} & \multicolumn{4}{|c|}{$2008 Q 4-2011 Q 3$} \\
\hline & (1) & (2) & (3) & (4) & (1) & (2) & (3) & (4) & (1) & (2) & (3) & (4) \\
\hline \multirow{2}{*}{ DEP\&NONDEP_TA } & -0.009 & & & -0.005 & 2.999 & & & & $-0.820^{* *}$ & & & \\
\hline & $(0.130)$ & & & $(0.132)$ & (3.074) & & & & $(0.376)$ & & & \\
\hline \multirow{2}{*}{ NONDEPOSITS_TA } & & $-0.054^{*}$ & & & & -0.052 & & & & $0.132^{*}$ & & \\
\hline & & $(0.032)$ & & & & $(0.252)$ & & & & $(0.074)$ & & \\
\hline \multirow{2}{*}{ DEPOSITS_TA } & & & $0.053^{*}$ & & & & 0.078 & & & & $-0.165^{* *}$ & \\
\hline & & & $(0.031)$ & & & & $(0.259)$ & & & & $(0.074)$ & \\
\hline \multirow{2}{*}{ NONDEPOSITS_TL } & & & & $-0.048^{*}$ & & & & -0.051 & & & & $0.125^{*}$ \\
\hline & & & & $(0.029)$ & & & & $(0.226)$ & & & & $(0.066)$ \\
\hline \multirow{2}{*}{ SIZE } & $3.610^{* * *}$ & $3.815^{* * *}$ & $3.840^{* * *}$ & $3.816^{* * *}$ & $-116.550^{*}$ & $-85.368^{*}$ & $-84.722^{*}$ & $-85.310^{*}$ & 1.913 & 1.385 & 1.253 & 1.320 \\
\hline & $(0.747)$ & $(0.754)$ & $(0.756)$ & $(0.758)$ & $(65.276)$ & $(49.201)$ & $(48.725)$ & $(49.030)$ & (1.914) & (1.978) & (1.983) & (1.979) \\
\hline \multirow{2}{*}{$R O A$} & 0.484 & 0.536 & $0.550^{*}$ & 0.538 & $6.260^{*}$ & $5.210^{*}$ & $5.269^{*}$ & $5.222^{*}$ & $0.688^{*}$ & $0.785^{* *}$ & $0.775^{* *}$ & $0.784^{* *}$ \\
\hline & $(0.324)$ & $(0.327)$ & $(0.328)$ & $(0.328)$ & $(3.223)$ & $(2.884)$ & $(2.920)$ & $(2.892)$ & $(0.388)$ & $(0.394)$ & $(0.395)$ & $(0.394)$ \\
\hline \multirow{2}{*}{ EQUITY_TA } & 0.153 & 0.114 & 0.162 & 0.124 & 3.493 & 0.418 & 0.492 & 0.427 & 0.082 & $1.017^{* * * *}$ & $0.863^{* *}$ & $1.013^{* * *}$ \\
\hline & $(0.168)$ & $(0.125)$ & $(0.123)$ & $(0.170)$ & $(3.566)$ & (1.889) & (1.932) & (1.893) & $(0.518)$ & $(0.352)$ & $(0.351)$ & $(0.353)$ \\
\hline \multirow{2}{*}{ CASH_TA } & -0.017 & -0.030 & -0.029 & -0.030 & $-1.926^{*}$ & $-1.934^{*}$ & $-1.908^{*}$ & $-1.932^{*}$ & -0.005 & 0.010 & 0.017 & 0.011 \\
\hline & $(0.040)$ & $(0.040)$ & $(0.040)$ & $(0.040)$ & (1.083) & $(0.997)$ & $(0.990)$ & $(0.995)$ & $(0.059)$ & $(0.060)$ & $(0.060)$ & $(0.060)$ \\
\hline \multirow{2}{*}{$M T B V$} & $0.008^{* * *}$ & $0.008^{* * *}$ & $0.008^{* * *}$ & $0.008^{* *}$ & $0.314^{* *}$ & $0.263^{* * *}$ & $0.265^{* * *}$ & $0.264^{* * *}$ & $0.015^{* *}$ & $0.013^{*}$ & $0.013^{*}$ & $0.013^{*}$ \\
\hline & $(0.003)$ & $(0.003)$ & $(0.003)$ & $(0.003)$ & $(0.136)$ & $(0.100)$ & $(0.100)$ & $(0.100)$ & $(0.007)$ & $(0.007)$ & $(0.007)$ & $(0.007)$ \\
\hline \multirow{2}{*}{ LOANS_TA } & -0.020 & -0.026 & -0.024 & -0.025 & -0.025 & 0.039 & 0.065 & 0.044 & -0.112 & -0.110 & -0.110 & -0.110 \\
\hline & $(0.029)$ & $(0.029)$ & $(0.029)$ & $(0.029)$ & $(0.519)$ & $(0.539)$ & $(0.541)$ & $(0.540)$ & $(0.074)$ & $(0.078)$ & $(0.077)$ & $(0.078)$ \\
\hline \multirow{2}{*}{$R W A \_T A$} & 0.021 & 0.019 & 0.018 & 0.018 & $-2.775^{* *}$ & $-2.247^{* *}$ & $-2.277^{* *}$ & $-2.254^{* *}$ & 0.045 & 0.026 & 0.027 & 0.025 \\
\hline & $(0.029)$ & $(0.035)$ & $(0.035)$ & $(0.035)$ & $(1.242)$ & $(0.902)$ & $(0.919)$ & $(0.907)$ & $(0.081)$ & $(0.087)$ & $(0.085)$ & $(0.086)$ \\
\hline \multirow{2}{*}{ INCOME_TAX_TA } & 0.062 & 0.106 & 0.100 & 0.107 & $-25.827^{* *}$ & $-19.900^{* *}$ & $-19.730^{* *}$ & $-19.890^{* *}$ & 1.629 & 0.978 & 1.127 & 0.991 \\
\hline & $(0.757)$ & $(0.758)$ & $(0.757)$ & $(0.758)$ & $(12.462)$ & $(9.689)$ & $(9.513)$ & $(9.627)$ & (1.478) & (1.477) & $(1.475)$ & $(1.478)$ \\
\hline \multirow{2}{*}{$E M P L_{-} C O M P$} & 0.005 & 0.008 & 0.008 & 0.008 & -0.278 & -0.204 & -0.204 & -0.204 & -0.004 & -0.006 & -0.007 & -0.006 \\
\hline & $(0.013)$ & $(0.013)$ & $(0.013)$ & $(0.013)$ & $(0.211)$ & $(0.174)$ & $(0.174)$ & $(0.174)$ & $(0.024)$ & $(0.024)$ & $(0.024)$ & $(0.024)$ \\
\hline \multirow{2}{*}{ CAPRATIO } & -0.047 & -0.031 & -0.032 & -0.032 & $-16.040^{* *}$ & $-12.376^{* *}$ & $-12.419^{* *}$ & $-12.392^{* *}$ & $-0.648^{* * *}$ & $-0.716^{* * *}$ & $-0.719^{* * *}$ & $-0.721^{* * *}$ \\
\hline & $(0.080)$ & $(0.081)$ & $(0.081)$ & $(0.081)$ & $(7.320)$ & (4.996) & $(5.002)$ & (4.995) & $(0.248)$ & $(0.251)$ & $(0.252)$ & $(0.252)$ \\
\hline Firm and Time Effects & Yes & Yes & Yes & Yes & Yes & Yes & Yes & Yes & Yes & Yes & Yes & Yes \\
\hline Pseudo- $R^{2}$ & 0.170 & 0.173 & 0.172 & 0.173 & 0.656 & 0.643 & 0.644 & 0.644 & 0.180 & 0.175 & 0.179 & 0.176 \\
\hline Observations & 1361 & 1361 & 1363 & 1363 & 106 & 106 & 106 & 106 & 578 & 578 & 578 & 578 \\
\hline
\end{tabular}




\begin{tabular}{|c|c|c|c|c|c|c|c|c|c|c|c|c|}
\hline \multirow{3}{*}{ Panel B } & \multicolumn{12}{|c|}{ DIVIDEND_EARNINGS } \\
\hline & \multicolumn{4}{|c|}{$2000 Q 1-2007 Q 3$} & \multicolumn{4}{|c|}{$2007 Q 4-2008 Q 3$} & \multicolumn{4}{|c|}{$2008 Q 4-2011 Q 3$} \\
\hline & (1) & (2) & (3) & (4) & (1) & (2) & (3) & (4) & (1) & (2) & (3) & (4) \\
\hline DIVIDEND_EARNI & $-0.205^{* * *}$ & $-0.206^{* * * *}$ & $-0.206^{\text {***** }}$ & $-0.205^{* * *}$ & $-0.422^{* * * *}$ & $-0.421^{* * *}$ & $-0.422^{* * *}$ & $-0.422^{* * *}$ & 0.023 & 0.024 & 0.023 & 0.023 \\
\hline$N G S(t-1)$ & $(0.040)$ & $(0.041)$ & $(0.041)$ & $(0.041)$ & $(0.094)$ & $(0.094)$ & $(0.094)$ & $(0.094)$ & $(0.051)$ & $(0.051)$ & $(0.051)$ & $(0.051)$ \\
\hline$D E P \& N O N D E P \_T$ & -1.031 & & & & -3.243 & & & & $-4.730^{*}$ & & & \\
\hline$A$ & $(1.153)$ & & & & (2.903) & & & & $(2.602)$ & & & \\
\hline NONDEPOSITS_T & & -0.184 & & & & -0.725 & & & & 1.031 & & \\
\hline$A$ & & $(0.201)$ & & & & $(0.698)$ & & & & $(0.727)$ & & \\
\hline \multirow{2}{*}{ DEPOSITS_TA } & & & 0.084 & & & & -0.578 & & & & $-1.332^{*}$ & \\
\hline & & & $(0.199)$ & & & & $(0.701)$ & & & & $(0.729)$ & \\
\hline NONDEPOSITS_T & & & & -0.154 & & & & -0.663 & & & & 0.960 \\
\hline$L$ & & & & $(0.183)$ & & & & $(0.628)$ & & & & $(0.651)$ \\
\hline \multirow{2}{*}{ SIZE } & -6.745 & -5.657 & -6.173 & -5.721 & -16.792 & -13.960 & -14.062 & -13.866 & $58.601^{* * *}$ & $59.358^{* * *}$ & $60.041^{* * *}$ & $59.289^{* * *}$ \\
\hline & $(4.528)$ & $(4.580)$ & $(4.583)$ & $(4.578)$ & $(41.751)$ & (41.657) & (41.464) & (41.705) & (21.779) & (21.743) & (21.708) & (21.716) \\
\hline \multirow{2}{*}{$R O A$} & $-35.911^{* * * *}$ & $-35.984^{* * *}$ & $-35.907^{* * *}$ & $-35.968^{* * * *}$ & $-53.751^{* * * *}$ & $-53.487^{* * *}$ & $-53.379^{* * *}$ & $-53.453^{* * *}$ & $-26.312^{* * *}$ & $-25.900^{* * * *}$ & $-26.076^{* * * *}$ & $-25.943^{* * * *}$ \\
\hline & $(5.360)$ & $(5.331)$ & $(5.320)$ & (5.329) & $(14.765)$ & $(14.590)$ & (14.564) & (14.593) & $(4.005)$ & (3.943) & $(3.961)$ & (3.948) \\
\hline \multirow{2}{*}{ EQUITY_TA } & 0.678 & $1.485^{* *}$ & $1.642^{* * *}$ & $1.514^{* *}$ & -2.605 & -0.250 & 0.493 & -0.168 & -6.222 & -0.425 & -1.409 & -0.466 \\
\hline & (1.238) & $(0.670)$ & $(0.623)$ & $(0.661)$ & (5.336) & (4.604) & $(4.432)$ & (4.585) & $(4.882)$ & (4.296) & $(4.241)$ & $(4.281)$ \\
\hline \multirow{2}{*}{ CASH_TA } & 0.129 & 0.094 & 0.120 & 0.096 & 0.099 & -0.189 & -0.179 & -0.200 & 0.873 & 0.935 & 0.994 & 0.944 \\
\hline & $(0.243)$ & $(0.251)$ & $(0.248)$ & $(0.252)$ & $(0.961)$ & $(0.929)$ & $(0.940)$ & $(0.935)$ & $(0.625)$ & $(0.634)$ & $(0.634)$ & (0.634) \\
\hline \multirow{2}{*}{$M T B V$} & $0.028^{*}$ & $0.026^{*}$ & $0.027^{*}$ & $0.026^{*}$ & 0.067 & 0.068 & 0.067 & 0.068 & $0.128^{*}$ & $0.124^{*}$ & $0.124^{*}$ & $0.124^{*}$ \\
\hline & $(0.016)$ & $(0.016)$ & $(0.016)$ & $(0.015)$ & $(0.066)$ & $(0.066)$ & $(0.066)$ & $(0.066)$ & $(0.068)$ & $(0.067)$ & $(0.067)$ & $(0.067)$ \\
\hline \multirow{2}{*}{ LOANS_TA } & -0.015 & -0.042 & -0.036 & -0.041 & 0.914 & 0.761 & 0.750 & 0.748 & -0.914 & -0.894 & -0.877 & -0.895 \\
\hline & $(0.167)$ & $(0.173)$ & $(0.172)$ & $(0.173)$ & (1.455) & $(1.472)$ & (1.477) & (1.473) & $(0.610)$ & $(0.632)$ & $(0.633)$ & $(0.632)$ \\
\hline \multirow{2}{*}{$R W A \_T A$} & -0.109 & -0.120 & -0.116 & -0.120 & -0.817 & -0.843 & -0.839 & -0.844 & $1.784^{* * *}$ & $1.653^{* *}$ & $1.637^{* *}$ & $1.645^{* *}$ \\
\hline & $(0.159)$ & $(0.159)$ & $(0.160)$ & $(0.159)$ & (1.112) & (1.116) & (1.114) & (1.117) & $(0.679)$ & (0.693) & $(0.690)$ & $(0.693)$ \\
\hline \multirow{2}{*}{$I N C O M E \_T A X \_T A$} & -2.836 & -2.795 & -2.797 & -2.791 & -0.320 & -0.302 & -0.314 & -0.302 & 10.182 & 8.101 & 8.092 & 8.036 \\
\hline & $(4.043)$ & (4.046) & (4.044) & (4.046) & $(0.406)$ & $(0.415)$ & $(0.417)$ & $(0.416)$ & $(8.647)$ & $(8.540)$ & $(8.552)$ & $(8.541)$ \\
\hline \multirow{2}{*}{$E M P L \_C O M P$} & 0.112 & 0.128 & 0.127 & 0.129 & -0.404 & -0.354 & -0.358 & -0.351 & 0.044 & 0.131 & 0.130 & 0.131 \\
\hline & $(0.104)$ & $(0.102)$ & $(0.102)$ & $(0.101)$ & $(0.501)$ & $(0.503)$ & $(0.499)$ & $(0.500)$ & $(0.122)$ & $(0.224)$ & $(0.224)$ & $(0.224)$ \\
\hline \multirow{2}{*}{ CAPRATIO } & -0.954 & -0.906 & -0.939 & -0.912 & -5.342 & -5.370 & -5.384 & -5.391 & 0.960 & 0.496 & 0.364 & 0.444 \\
\hline & $(0.586)$ & $(0.583)$ & $(0.583)$ & $(0.579)$ & (3.774) & (3.787) & (3.783) & (3.785) & (2.015) & $(1.200)$ & (1.997) & (1.998) \\
\hline \multirow{2}{*}{ Constant } & $255.443^{*}$ & $145.746^{* *}$ & $141.772^{* *}$ & $146.111^{* *}$ & 749.287 & 418.944 & 360.786 & -418.132 & -378.069 & $-864.534^{* * *}$ & $-748.972^{* *}$ & $-862.397^{* * *}$ \\
\hline & (132.240) & $(65.753)$ & (69.430) & (65.679) & (767.491) & (657.122) & (661.803) & $(657.103)$ & (403.914) & (335.648) & (332.206) & (334.918) \\
\hline Firm and Time & Yes & Yes & Yes & Yes & Yes & Yes & Yes & Yes & Yes & Yes & Yes & Yes \\
\hline$R^{2}$ (within) & 0.164 & 0.164 & 0.164 & 0.164 & 0.280 & 0.280 & 0.280 & 0.280 & 0.150 & 0.149 & 0.151 & 0.150 \\
\hline Observations & 5292 & 5292 & 5294 & 5292 & 887 & 887 & 887 & 887 & 2403 & 2403 & 2403 & 2403 \\
\hline
\end{tabular}




\begin{tabular}{|c|c|c|c|c|c|c|c|c|c|c|c|c|}
\hline \multirow{3}{*}{ Panel C } & \multicolumn{12}{|c|}{ DIVIDEND_EQUITY } \\
\hline & \multicolumn{4}{|c|}{$2000 Q 1-2007 Q 3$} & \multicolumn{4}{|c|}{$2007 Q 4-2008 Q 3$} & \multicolumn{4}{|c|}{$2008 Q 4-2011 Q 3$} \\
\hline & (1) & (2) & (3) & (4) & (1) & (2) & (3) & (4) & (1) & (2) & (3) & (4) \\
\hline \multirow{2}{*}{ DIVIDEND_EQUITY $(t-1)$} & $-0.387^{* * *}$ & $-0.387^{* * *}$ & $-0.387^{* * *}$ & $-0.387^{* * *}$ & $-0.424^{* * *}$ & $-0.424^{* * *}$ & $-0.424^{* * *}$ & $-0.424^{* * *}$ & -0.075 & -0.078 & -0.078 & -0.078 \\
\hline & $(0.043)$ & $(0.043)$ & $(0.043)$ & $(0.043)$ & $(0.077)$ & $(0.076)$ & $(0.076)$ & $(0.076)$ & $(0.064)$ & $(0.063)$ & $(0.064)$ & $(0.063)$ \\
\hline \multirow{2}{*}{$D E P \& N O N D E P \_T A$} & -0.042 & & & & -0.141 & & & & -0.021 & & & \\
\hline & $(0.032)$ & & & & $(0.111)$ & & & & $(0.015)$ & & & \\
\hline \multirow[b]{2}{*}{ NONDEPOSITS_TA } & & -0.001 & & & & -0.028 & & & & $0.049^{* * *}$ & & \\
\hline & & $(0.011)$ & & & & $(0.033)$ & & & & $(0.014)$ & & \\
\hline \multirow{2}{*}{ DEPOSITS_TA } & & & -0.004 & & & & 0.018 & & & & $-0.045^{* * *}$ & \\
\hline & & & $(0.011)$ & & & & $(0.031)$ & & & & $(0.012)$ & \\
\hline \multirow{2}{*}{ NONDEPOSITS_TL } & & & & 0.001 & & & & 0.028 & & & & $0.044^{* * *}$ \\
\hline & & & & $(0.010)$ & & & & $(0.029)$ & & & & $(0.013)$ \\
\hline \multirow{2}{*}{ SIZE } & -0.391 & -0.366 & -0.389 & -0.366 & $2.271^{*}$ & $3.070^{*}$ & $3.050^{*}$ & $3.099^{*}$ & $1.075^{* * *}$ & $1.177^{* * *}$ & $1.124^{* * *}$ & $1.170^{* * *}$ \\
\hline & $(0.324)$ & $(0.339)$ & $(0.340)$ & $(0.338)$ & (1.605) & (1.683) & (1.688) & (1.693) & $(0.310)$ & $(0.314)$ & $(0.314)$ & $(0.314)$ \\
\hline \multirow{2}{*}{$R O A$} & -0.005 & -0.008 & -0.005 & -0.008 & 0.038 & 0.036 & 0.034 & 0.036 & $0.040^{* * * *}$ & $0.041^{\text {**** }}$ & $0.040^{* * *}$ & $0.041^{* * * *}$ \\
\hline & $(0.062)$ & $(0.063)$ & $(0.063)$ & $(0.063)$ & $(0.057)$ & $(0.057)$ & $(0.057)$ & $(0.057)$ & $(0.011)$ & $(0.011)$ & $(0.011)$ & $(0.011)$ \\
\hline \multirow{2}{*}{ EQUITY_TA } & $-0.096^{* *}$ & $-0.057^{* *}$ & $-0.059^{* *}$ & $-0.057^{* *}$ & $-0.237^{*}$ & -0.105 & -0.083 & -0.105 & 0.028 & 0.071 & 0.028 & 0.066 \\
\hline & $(0.041)$ & $(0.029)$ & $(0.029)$ & $(0.029)$ & $(0.129)$ & $(0.070)$ & $(0.072)$ & $(0.070)$ & $(0.046)$ & $(0.046)$ & $(0.046)$ & $(0.045)$ \\
\hline \multirow{2}{*}{$C A S H \_T A$} & -0.011 & -0.012 & -0.011 & -0.012 & $-0.031^{*}$ & -0.042 & -0.041 & -0.043 & $0.032^{* * * *}$ & $0.037^{* * * *}$ & $0.038^{* * *}$ & $0.037^{* * *}$ \\
\hline & $(0.011)$ & $(0.011)$ & $(0.011)$ & $(0.011)$ & $(0.027)$ & $(0.029)$ & $(0.029)$ & $(0.029)$ & $(0.012)$ & $(0.012)$ & $(0.012)$ & $(0.012)$ \\
\hline \multirow{2}{*}{$M T B V$} & $0.005^{* * *}$ & $0.005^{* * *}$ & $0.005^{* * *}$ & $0.005^{* * *}$ & $0.011^{* * *}$ & $0.011^{* * * *}$ & $0.011^{* * *}$ & $0.011^{* * * *}$ & $0.007^{* * * *}$ & $0.007^{* * *}$ & $0.007^{* * *}$ & $0.008^{* * *}$ \\
\hline & $(0.001)$ & $(0.001)$ & $(0.001)$ & $(0.001)$ & $(0.003)$ & $(0.003)$ & $(0.003)$ & $(0.003)$ & $(0.002)$ & $(0.001)$ & $(0.001)$ & $(0.001)$ \\
\hline \multirow{2}{*}{$L O A N S \_T A$} & -0.008 & -0.010 & -0.009 & -0.010 & $0.068^{*}$ & 0.060 & 0.060 & 0.060 & 0.015 & 0.014 & 0.020 & 0.015 \\
\hline & $(0.012)$ & $(0.012)$ & $(0.012)$ & $(0.012)$ & $(0.041)$ & $(0.040)$ & $(0.040)$ & $(0.040)$ & $(0.011)$ & $(0.010)$ & $(0.011)$ & $(0.011)$ \\
\hline \multirow{2}{*}{$R W A \_T A$} & 0.006 & 0.007 & 0.007 & 0.007 & 0.005 & 0.007 & 0.008 & 0.008 & 0.007 & 0.009 & 0.005 & 0.008 \\
\hline & $(0.011)$ & $(0.011)$ & $(0.011)$ & $(0.011)$ & $(0.042)$ & $(0.042)$ & $(0.042)$ & $(0.042)$ & $(0.015)$ & $(0.014)$ & $(0.014)$ & $(0.014)$ \\
\hline \multirow{2}{*}{$I N C O M E \_T A X \_T A$} & -0.078 & -0.071 & -0.075 & -0.071 & 0.018 & 0.019 & 0.018 & 0.019 & $0.442^{* *}$ & $0.399^{*}$ & $0.436^{* *}$ & $0.401^{*}$ \\
\hline & $(0.257)$ & $(0.256)$ & $(0.256)$ & $(0.256)$ & $(0.017)$ & $(0.017)$ & $(0.017)$ & $(0.017)$ & $(0.212)$ & $(0.208)$ & $(0.209)$ & $(0.208)$ \\
\hline \multirow{2}{*}{$E M P L \_C O M P$} & -0.008 & -0.008 & -0.008 & -0.008 & 0.007 & 0.008 & 0.008 & 0.008 & 0.002 & 0.002 & 0.002 & 0.002 \\
\hline & $(0.005)$ & $(0.005)$ & $(0.005)$ & $(0.005)$ & $(0.006)$ & $(0.007)$ & $(0.007)$ & $(0.007)$ & $(0.004)$ & $(0.004)$ & $(0.004)$ & $(0.004)$ \\
\hline \multirow{2}{*}{ CAPRATIO } & -0.005 & -0.004 & -0.003 & -0.004 & 0.066 & $0.073^{*}$ & 0.071 & $0.073^{*}$ & $-0.060^{*}$ & $-0.069^{* *}$ & $-0.070^{* *}$ & $-0.070^{* *}$ \\
\hline & $(0.016)$ & $(0.016)$ & $(0.016)$ & $(0.016)$ & $(0.042)$ & $(0.043)$ & $(0.043)$ & $(0.043)$ & $(0.034)$ & $(0.034)$ & $(0.034)$ & $(0.034)$ \\
\hline \multirow{2}{*}{ Constant } & $13.978^{* *}$ & $9.679^{* *}$ & $10.231^{* *}$ & $9.677^{* *}$ & -25.573 & $-43.706^{*}$ & $-45.347^{*}$ & $-44.068^{*}$ & $-11.858^{* *}$ & $-16.230^{* * * *}$ & $-11.170^{* *}$ & $-16.108^{* * * *}$ \\
\hline & $(5.724)$ & $(4.665)$ & (5.079) & $(4.667)$ & (26.518) & (25.811) & (26.887) & (25.935) & (4.984) & $(5.070)$ & $(4.878)$ & $(5.081)$ \\
\hline Firm and Time Effects & Yes & Yes & Yes & Yes & Yes & Yes & Yes & Yes & Yes & Yes & Yes & Yes \\
\hline$R^{2}$ (within) & 0.167 & 0.167 & 0.167 & 0.167 & 0.256 & 0.255 & 0.255 & 0.256 & 0.137 & 0.142 & 0.142 & 0.142 \\
\hline Observations & 5647 & 5647 & 5650 & 5647 & 1146 & 1146 & 1146 & 1146 & 3945 & 3945 & 3945 & 3945 \\
\hline
\end{tabular}

Each panel estimates regression models across the following three sample periods: 2000q1-2007q3; 2007q4-2008q3; 2008q4-2011q3. Panel A: Coefficients estimated by a Logit model for DIVIDEND_DUMMY on the variables for leverage, the control variables, and a set of dummies for banks and quarters (not reported). For every sub-period, the columns differ in the variable for leverage. Standard errors are reported in parentheses. Panel B: Coefficients estimated by an Ordinary Least Squares (OLS) model for DIVIDEND_EARNINGS on the variables for leverage, the control 
variables, the lagged value of DIVIDEND_EARNINGS, and a set of dummies for banks and quarters (not reported). For every sub-period, the columns differ in the variable for leverage. DIVIDEND_EARNINGS is winsorized at the $1 \%$ and 99\% level. Standard errors are clustered at the bank level and are reported in parentheses. Panel C: Coefficients estimated by an Ordinary Least Squares (OLS) model for DIVIDEND_EQUITY on the variables for leverage, the control variables, the lagged value of DIVIDEND_EQUITY, and a set of dummies for banks and quarters (not reported). For every sub-period, the columns differ in the variable for leverage. DIVIDEND_EQUITY is winsorized at the $1 \%$ and $99 \%$ level. Standard errors are clustered at the bank level and are reported in parentheses. Significance: ${ }^{*} \mathrm{p}<0.10$, ${ }^{* * *} \mathrm{p}<0.05,{ }^{* * * *} \mathrm{p}<0.01$

\subsection{Results}

In the panels of Table 5 we focus on the coefficients estimated on the variables for leverage. During 2000-2006 there are no significant coefficients from leverage on the two payout measures, except for a weak negative effect from non-deposit leverage on DIVIDEND_DUMMY. During 2007-2008 the sign on leverage is never statistically relevant.

Instead, the coefficients on leverage become statistically much more important during the last part of the sample, namely during 2008-2011. In the aftermath of the crisis the link between banks' dividends and leverage is more evident. Interestingly, we observe a heterogeneous pattern. In general, dividends are negatively correlated to deposit leverage, while positively correlated to non-deposit leverage. The impact is stronger on the payout ratio measured from DIVIDEND_EQUITY. In economic terms, a marginal increase in DEPOSITS_TA reduces DIVIDEND_EQUITY by almost $44 \%$. (Note 5 )

Looking at the coefficients on the control regressors, the pattern in the sign differs across the three panels, although the significance is not very striking. The variability in the two payout measures is largely captured by their one-period lagged values, given the high and significant coefficients on the first lags of the dependent variables. (Note 6) Investment opportunities $(M T B V)$ are often positive on dividends, while there is a remarkable size effect on the dividend payout after 2008. (Note 7)

\subsection{Interpretation of the Results}

We now interpret the outcomes got in the previous sub-section. The major finding is that different components of the bank' s leverage are differently related to the dividend policy of the same firm. Our banks are more encouraged to pay out dividends when they raise their non-deposit debt, while they are less willing to pay dividends when they increase in deposits. Our results suggest that depositors can discipline banks, which do not pay out earnings when increase deposits. On the other hand instead, paying dividends seems to be a way for banks to shift risk on the non-deposit debtholders, given that dividends are positively correlated with non-deposits.

This pattern becomes statistically more interesting with the outbreak of crisis. We interpret how the crisis has influenced the financing of commercial banks, and ultimately their dividends. The crisis revealed severe troubles in the market of wholesale debt. Several banks experienced distress after the freezing of interbank short-term credit. In order to face the consequences of the turmoil and return to stability, banks had to change their funding models. Oura et al. (2013) note that with the crisis, United States banks started raising equity capital, while replacing secured and unsecured wholesale debt with deposits. Collecting new deposits, banks could hoard the liquidity which was rapidly drying up in the unsecured interbank market (Heider, Hoerova, and Holthausen (2009)). Boyson, Helwege, and Jindra (2014) say that through deposit funding banks can avoid fire sales of assets due to liquidity shocks during crises. There are several papers which mention that during episodes of crisis banks change their financing strategies towards the inclusion of more deposits. Among others we refer to Hoggarth, Mahadeva, and Martin (2010), Adrian and Shin (2011), Martel, Van Rixtel, and González Mota (2012), and Van Rixtel and Gasperini (2013). Berrospide (2012) studies the determinants for the liquidity hoarding of banks during the recent crisis. The author notes the importance of deposits for smaller banks, which have restricted access to interbank markets and to the central bank's discount window. By hoarding liquidity through deposits, smaller banks can more easily purchase government securities and mortgage-backed securities. According to Berrospide (2012), during the height of the crisis in 2008, the liquidity stemming from deposits diminished, since depositors lost confidence, and started withdrawing.

Episodes of turmoil inside financial markets may affect the behavior of depositors, who see their funds at risk (for example, see the evidence in Gatev, Schuermann, and Strahan (2007), and Martinez Peria and Schmuckler (2001)). In particular, during 2007-2009 banks were no more regarded as safe havens and passive recipient of funds as it was during previous crises, while they were active in seeking deposits (Mora (2010) and Acharya and Mora (2012)). Calomiris and Kahn (1991) and Calomiris (2012) say that most frequent and severe cause for funding illiquidity is 
the withdrawals from liquidity providers due to the perception of an increased risk in the firm solvency. Arguably, during the latest financial crisis depositors started fearing the uncertainty on banks' financial conditions. Due to bank failures during 2008-2009, the FDIC fund fell to $\$ 0.648$ billion by August 2009. Subsequent failures of financial firms almost bankrupted the FDIC, so that it demanded a 3-year pre-payment from banks to shore up its capital. At the close of 2009, a total of 140 banks became insolvent. This is the largest number of bank failures in a year since 1992, when 179 institutions failed. In our view, all the facts mentioned above support our argument that during the crisis banks gave crucial importance to depositors and did not want to deprive them of value by paying out cash.

On the other hand, the estimated coefficient on the non-deposit leverage is positive. Namely, by paying dividends banks shift the owners' risk on the non-deposit creditors, who hold a minor share of the debt inside commercial banks. Some previous discussions argue that banks funded more by non-deposit liabilities fared worse during the crisis, and had to seek retail funding in order to face the distress (Huang and Ratnovski (2009), Shin (2009), Demirgüç-Kunt and Huizinga (2010), Goldsmith-Pinkham and Yorulmazer (2010), Beltratti and Stulz (2012), and Vazquez and Federico (2012)). (Note 8)

\section{Testing Effects on the Results from Signaling and Disciplining Arguments}

In this section we want to stress the plausibility of our previous interpretation by verifying to what extent the results are affected by other opinions, which argue that dividends can be explained by signaling and disciplining hypotheses.

\subsection{Effects from Signaling on the Results}

Several studies have discussed how both dividends and debt issuances can signal the firm's profitability. If managers are asymmetrically more informed than the outside investors on future business prospects, they might want to signal their future profitability by paying out cash or by raising debt. (Note 9)

In order to stress to what extent profitability issues are driving our outcomes, in Table 6 we display results where the covariates include the interaction term between leverage and the return on assets, namely the indicator for profitability we employed in all the previous estimates. Given the difficulties in interpreting the interaction between continuous variables (Jaccard, Turrisi and Wan (1990)), we further show estimates where the interacted variables are centered about their respective means. In the columns of Table 6 the interactions are never significant. For example, in column 3 we do not see that profitability sorts an interesting effect on dividends for a bank with average deposit leverage. To conclude, we do not get evidence hinting that the previously estimated results and the interpretation we provided, are importantly driven by signaling arguments.

Table 6 . The effect from leverage on banks' dividends, including the interaction between leverage and profitability

\begin{tabular}{|c|c|c|c|c|}
\hline & \multicolumn{2}{|c|}{ DIVIDEND_DUMMY } & \multicolumn{2}{|c|}{ DIVIDEND_EQUITY } \\
\hline & (1) & (2) & (3) & (4) \\
\hline NONDEPOSITS_TA & $\begin{array}{c}0.105 \\
(0.082)\end{array}$ & & $\begin{array}{c}0.049^{* * * *} \\
(0.015)\end{array}$ & \\
\hline DEPOSITS_TA & & $\begin{array}{l}-0.119 \\
(0.082)\end{array}$ & & $\begin{array}{c}-0.045^{* * *} \\
(0.013)\end{array}$ \\
\hline$R O A$ & $\begin{array}{c}0.561 \\
(0.496)\end{array}$ & $\begin{array}{c}6.146 \\
(4.483)\end{array}$ & $\begin{array}{c}0.042^{*} \\
(0.023)\end{array}$ & $\begin{array}{l}-0.041 \\
(0.121)\end{array}$ \\
\hline NONDEPOSITS_TA*ROA & $\begin{array}{c}0.041 \\
(0.058)\end{array}$ & & $\begin{array}{l}-0.000 \\
(0.002)\end{array}$ & \\
\hline DEPOSITS_TA*ROA & & $\begin{array}{l}-0.066 \\
(0.054)\end{array}$ & & $\begin{array}{l}-0.000 \\
(0.002)\end{array}$ \\
\hline Control Variables \& Fixed Effect & Yes & Yes & Yes & Yes \\
\hline
\end{tabular}

Mean-Centered Variables:

\begin{tabular}{|c|c|c|c|c|}
\hline NONDEPOSITS_TA & $\begin{array}{l}0.131^{*} \\
(0.074)\end{array}$ & & $\begin{array}{c}0.047^{* * *} \\
(0.014)\end{array}$ & \\
\hline DEPOSITS_TA & & $\begin{array}{c}-0.161^{\text {** }} \\
(0.074)\end{array}$ & & $\begin{array}{c}-0.043^{* * *} \\
(0.012)\end{array}$ \\
\hline$R O A$ & 0.588 & 6.104 & $0.035^{*}$ & 0.071 \\
\hline
\end{tabular}




$\begin{array}{lr} & (0.474 \\ & 0.041 \\ & (0.058\end{array}$

DEPOSITS_TA*ROA
(4.448)

$(0.020)$

0.000

$(0.002)$

$-0.066$

(0.054)
$(0.114)$

$-0.000$

$(0.001)$

Control Variables \& Fixed Effect

Yes

Yes

Yes

Yes

Each column estimates regression models during the sample period 2008q4-2011q3. Columns 1-2: Coefficients estimated by a Logit model for DIVIDEND_DUMMY. The set of regressors includes also the following variables, which are not reported in the table: SIZE, ROA, EQUITY_TA, CASH_TA, MTBV, LOANS_TA, RWA_TA, INCOME_TAX_TA, EMPL_COMP, CAPRATIO, and a set of dummies for banks and quarters. Standard errors are reported in parentheses. Columns 3-4: Coefficients estimated by an Ordinary Least Squares (OLS) model for DIVIDEND_EQUITY. The set of regressors includes also the following variables, which are not reported in the table: DIVIDEND_EQUITY (t-1),SIZE, ROA, EQUITY_TA, CASH_TA, MTBV, LOANS_TA, RWA_TA, INCOME_TAX_TA, EMPL_COMP, CAPRATIO, a constant, and a set of dummies for banks and quarters. DIVIDEND_EQUITY is winsorized at the 1\% and 99\% level. Standard errors are clustered at the bank level and are reported in parentheses. Significance: ${ }^{*} \mathrm{p}<0.10,{ }^{* *} \mathrm{p}<0.05,{ }^{* * *} \mathrm{p}<0.01$

\subsection{Effects from Disciplining on the Results}

Dividends and leverage can both serve to discipline managers. Indeed, managers might be tempted to use the exceeding cash flows for pursuing their own goals, rather than for growing the business. Dividends can discipline the excesses of mangers, since they force managers to return funds to owners. At the same time, also the issuance of debt is a way to concentrate managers in running the firm efficiently, because managers will feel pressured to keep the firm solvable, and will be less tempted to destroy value. (Note 10)

In order to get some evidence on the outcomes due to disciplining arguments, we exploit the available information on the banks' share of insider ownership measured during 2011q3. (Note 11) LOW_INSIDER_DUMMY is a dummy variable denoting with value one whether the bank has insider ownership below the mean (which equals 18.2\%). Inside banks with lower insider ownership, managers could be more likely to misbehave, therefore firms would need a stronger monitor on managerial actions. In Table 7 we let interact $L O W \_I N S I D E R \_D U M M Y$ with deposit and non-deposit leverage. These latter interaction terms are never statistically relevant. Hence, we cannot argue that the banks which need more discipline, use leverage as a substitute of dividends in the control of managers, neither the two policies complement each other with a relevant joint effect. In conclusion, surveying the governance structure of our banks does not improve the previous interpretation.

Table 7. The effect from leverage on banks' dividends, including the interaction between leverage and insider ownership

\begin{tabular}{ccccccc}
\hline & \multicolumn{2}{c}{ DIVIDEND_DUMMY } & \multicolumn{2}{c}{ DIVIDEND_EARNINGS } & \multicolumn{2}{c}{ DIVIDEND_EQUITY } \\
& $(1)$ & $(2)$ & $(3)$ & $(4)$ & $(5)$ & $(6)$ \\
\hline & $0.192^{*}$ & & 0.265 & & 0.021 & \\
NONDEPOSITS_TA & $(0.110)$ & & $(1.355)$ & & $(0.021)$ & \\
& & $-0.270^{* *}$ & & -0.607 & & $-0.029^{*}$ \\
DEPOSITS_TA & & $(0.112)$ & & $(1.346)$ & & $(0.015)$ \\
NONDEPOSITS_TA* & -0.116 & & 0.932 & & 0.032 & \\
LOW_INSIDER_DUMMY & $(0.123)$ & & $(1.369)$ & & $(0.026)$ & \\
DEPOSITS_TA* & & 0.176 & & -0.829 & & -0.016 \\
LOW_INSIDER_DUMMY & & $(0.121)$ & & $(1.336)$ & & $(0.019)$ \\
Control Variables & Yes & Yes & Yes & Yes & Yes & Yes \\
Firm and Time Effects & Yes & Yes & Yes & Yes & Yes & Yes \\
\hline Pseudo- $R^{2} / R^{2}$ (within) & 0.176 & 0.184 & 0.161 & 0.162 & 0.155 & 0.155 \\
Observations & 521 & 521 & 2258 & 2258 & 3657 & 3657 \\
\hline
\end{tabular}


Each column estimates regression models during the sample period 2008q4-2011q3. LOW_INSIDER_DUMMY is a dichotomous variable which assumes value one if the bank has got insider ownership smaller or equal than the mean insider ownership across the sample (equal to 18.231\%). Columns 1-2: Coefficients estimated by a Logit model for DIVIDEND_DUMMY. The set of regressors includes also the following variables, which are not reported in the table: SIZE, ROA, EQUITY_TA, CASH_TA, MTBV, LOANS_TA, RWA_TA, INCOME_TAX_TA, EMPL_COMP, CAPRATIO, and a set of dummies for banks and quarters. Standard errors are reported in parentheses. Columns 3-4: Coefficients estimated by an Ordinary Least Squares (OLS) model for DIVIDEND_EARNINGS. The set of regressors includes also the following variables, which are not reported in the table: DIVIDEND_EARNINGS (t-1), SIZE, ROA, EQUITY_TA, CASH_TA, MTBV, LOANS_TA, RWA_TA, INCOME_TAX_TA, EMPL_COMP, CAPRATIO, a constant, and a set of dummies for banks and quarters. DIVIDEND_EARNINGS is winsorized at the $1 \%$ and $99 \%$ level. Standard errors are clustered at the bank level and are reported in parentheses. Columns 5-6: Coefficients estimated by an Ordinary Least Squares (OLS) model for DIVIDEND_EQUITY. The set of regressors includes also the following variables, which are not reported in the table: DIVIDEND_EQUITY (t-1), SIZE, ROA, EQUITY_TA, CASH_TA, MTBV, LOANS_TA, RWA_TA, INCOME_TAX_TA, EMPL_COMP, CAPRATIO, a constant, and a set of dummies for banks and quarters. DIVIDEND_EQUITY is winsorized at the $1 \%$ and $99 \%$ level. Standard errors are clustered at the bank level and are reported in parentheses. Significance: ${ }^{*} \mathrm{p}<0.10,{ }^{* *} \mathrm{p}<0.05,{ }^{* * *} \mathrm{p}<0.01$

\section{Additional Tests}

\subsection{Disentangling Effects on Dividends from Different Types of Deposits}

We disentangle the contribution on dividends from various types of deposits. Table 8 displays that our banks have more than the $50 \%$ of their assets funded through current accounts (CURRENTACC_TA) and "time deposits." Time deposits are separated into jumbo time deposits and retail time deposits (respectively, JUMBOTIMEDEP_TA and RETAILTIMEDEP_TA). A lower share of assets is financed from money market accounts (MONEYMKTACC_TA) and saving accounts (SAVINGACC_TA), while very marginal is the proportion over assets on foreign deposits (FOREIGNDEP_TA) and other unclassified deposits (OTHERDEP_TA).

Table 8. The composition of banks' deposit leverage

\begin{tabular}{ccccccccc}
\hline Variable & $\begin{array}{c}\mathrm{N}(\text { as of } \\
2011 \mathrm{Q} 3)\end{array}$ & Mean & Median & $5 \%$ & $25 \%$ & $75 \%$ & $95 \%$ & Std. Dev \\
\hline DEPOSITS_TA & 981 & 78.928 & 80.980 & 62.340 & 74.690 & 85.470 & 89.820 & 9.685 \\
JUMBOTIMEDEP_TA & 981 & 14.589 & 12.984 & 4.376 & 8.742 & 18.930 & 30.077 & 8.133 \\
RETAILTIMEDEP_TA & 981 & 19.204 & 19.121 & 3.510 & 12.216 & 25.685 & 35.841 & 9.746 \\
MONEYMKTACC_TA & 981 & 14.952 & 12.872 & 2.354 & 7.583 & 20.267 & 34.648 & 10.149 \\
SAVINGACC_TA & 981 & 8.558 & 5.962 & 0.233 & 2.451 & 11.730 & 27.086 & 8.554 \\
CURRENTACC_TA & 981 & 21.831 & 21.063 & 7.189 & 14.723 & 27.808 & 39.535 & 9.962 \\
FOREIGNDEP_TA & 981 & 0.230 & 0.000 & 0.000 & 0.000 & 0.000 & 0.000 & 2.300 \\
OTHERDEP_TA & 981 & 0.021 & 0.000 & 0.000 & 0.000 & 0.000 & 0.000 & 0.837 \\
\hline
\end{tabular}

The table reports the average percentage value of the variables during the sample period 2000q1-2011q3.

In Table 9 we estimate models (1) and (2) replacing the variable for deposit leverage with the six disentangled types of deposits. On average, we observe that all deposits have important negative effects on dividends. We comment briefly on time deposits. Time deposits can be withdrawn only after a specified date, typically ranging from three months to six years. Jumbo time deposits have balance of at least $\$ 100,000$ and do not have the FDIC insurance protection, hence entail higher investment risk. Conversely, retail time deposits are fully protected from the FDIC. In Table 9 the effects from the two types of time deposits are not different in sign, neither in significance. Hence, we deduce that our banks do not want to pay dividends as long as deposits become wider, even when deposits have full deposit insurance. (Note 12) 
Table 9. The effect from the components of deposit leverage on banks' dividends

DIVIDEND_DUMMY

(1)
DIVIDEND_EARNINGS

(2)
DIVIDEND_EQUITY

(3)

\begin{tabular}{|c|c|c|c|}
\hline Type of Deposits: & & & \\
\hline JUMBOTIMEDEP_TA & $\begin{array}{l}-0.362^{* *} \\
(0.182)\end{array}$ & $\begin{array}{l}-2.166^{*} \\
(1.483)\end{array}$ & $\begin{array}{l}-0.049^{* *} \\
(0.022)\end{array}$ \\
\hline RETAILTIMEDEP_TA & $\begin{array}{l}-0.640^{* * * *} \\
(0.236)\end{array}$ & $\begin{array}{l}-2.453^{*} \\
(1.440)\end{array}$ & $\begin{array}{c}-0.084^{* * *} \\
(0.024)\end{array}$ \\
\hline MONEYMKTACC_TA & $\begin{array}{l}-0.375^{* *} \\
(0.181)\end{array}$ & $\begin{array}{l}-2.464 \\
(1.630)\end{array}$ & $\begin{array}{l}-0.042^{* *} \\
(0.021)\end{array}$ \\
\hline SAVINGACC_TA & $\begin{array}{l}-1.193^{* *} \\
(0.482)\end{array}$ & $\begin{array}{l}-3.031^{*} \\
(1.583)\end{array}$ & $\begin{array}{l}-0.079^{* *} \\
(0.035)\end{array}$ \\
\hline CURRENTACC_TA & $\begin{array}{l}-0.403^{*} \\
(0.226)\end{array}$ & $\begin{array}{c}-3.489^{* *} \\
(1.401)\end{array}$ & $\begin{array}{c}-0.046^{* * *} \\
(0.022)\end{array}$ \\
\hline FOREIGNDEP_TA & $\begin{array}{c}-4.728 \\
\left(5.87 \mathrm{e}^{\wedge} 04\right)\end{array}$ & $\begin{array}{l}-2.237 \\
(3.679)\end{array}$ & $\begin{array}{l}-0.248^{*} \\
(0.136)\end{array}$ \\
\hline Control Variables & Yes & Yes & Yes \\
\hline Firm and Time Effects & Yes & Yes & Yes \\
\hline \multicolumn{4}{|l|}{ Dummy for: } \\
\hline$\triangle D E P O S I T S<0$ & $\begin{array}{l}-0.538^{* *} \\
(0.254)\end{array}$ & $\begin{array}{l}-0.075 \\
(2.137)\end{array}$ & $\begin{array}{l}-0.084 \\
(0.051)\end{array}$ \\
\hline $\begin{array}{c}\triangle D E P O S I T S \text { (Excluded TIME } \\
\text { DEPOSITS) }<0\end{array}$ & $\begin{array}{l}-0.738^{* * *} \\
(0.275)\end{array}$ & $\begin{array}{l}-1.016 \\
(2.381)\end{array}$ & $\begin{array}{l}-0.139^{* *} \\
(0.065)\end{array}$ \\
\hline Control Variables & Yes & Yes & Yes \\
\hline Firm and Time Effects & Yes & Yes & Yes \\
\hline
\end{tabular}

Each column estimates regression models during the sample period 2008q4-2011q3. The variables for the type of deposits are defined in the Appendix. $\triangle D E P O S I T S$ is the difference in the value of deposits across two consecutive quarters. Column 1: Coefficients estimated by a Logit model for DIVIDEND_DUMMY. The set of regressors includes also the following variables, which are not reported in the table: SIZE, ROA, EQUITY_TA, CASH_TA, MTBV, LOANS_TA, RWA_TA, INCOME_TAX_TA, EMPL_COMP, CAPRATIO, and a set of dummies for banks and quarters. Standard errors are reported in parentheses. Column 2: Coefficients estimated by an Ordinary Least Squares (OLS) model for DIVIDEND_EARNINGS. The set of regressors includes also the following variables, which are not reported in the table: DIVIDEND_EARNINGS (t-1), SIZE, ROA, EQUITY_TA, CASH_TA, MTBV, LOANS_TA, RWA_TA, INCOME_TAX_TA, EMPL_COMP, CAPRATIO, a constant, and a set of dummies for banks and quarters. DIVIDEND_EARNINGS is winsorized at the $1 \%$ and $99 \%$ level. Standard errors are clustered at the bank level and are reported in parentheses. Column 3: Coefficients estimated by an Ordinary Least Squares (OLS) model for DIVIDEND_EQUITY. The set of regressors includes also the following variables, which are not reported in the table: DIVIDEND_EQUITY (t-1),SIZE, ROA, EQUITY_TA, CASH_TA, MTBV, LOANS_TA, RWA_TA, INCOME_TAX_TA, EMPL_COMP, CAPRATIO, a constant, and a set of dummies for banks and quarters. DIVIDEND_EQUITY is winsorized at the $1 \%$ and $99 \%$ level. Standard errors are clustered at the bank level and are reported in parentheses. Significance: ${ }^{*} \mathrm{p}<0.10,{ }^{* *} \mathrm{p}<0.05,{ }^{* * * *} \mathrm{p}<0.01$

\subsection{Disentangling the Effect on Dividends from the Change in Deposits}

We explore the evolution in the change of deposits between two consecutive quarters. In Table 9 above the change in deposits is denoted with the symbol "delta." When delta is negative, withdrawals reduce the aggregate value of deposits from one quarter to the other. Among the covariates of models (1) and (2), we add a dichotomous variable 
assuming value one if delta is negative. The sign estimated on the dummy is negative, although relevant only on DIVIDEND_DUMMY.

We find more interesting outputs as soon as we consider the value of deposits subtracted from the value of time deposits. Thus, we create a dummy variable taking value one when there is a negative change in the bank non-time deposits, namely current accounts, money market accounts, saving accounts, foreign and other type of deposits. This latter dummy is now significantly negative on DIVIDEND_DUMMY and DIVIDEND_EQUITY. Non-time deposits can be withdrawn more easily than time deposits, and we find plausible to think that the bank finds more difficult to estimate how long these funds would be available. If the firm fears the behavior of non-time depositors, we can explain why the negative effect on dividends becomes more evident for the non-time deposits.

\subsection{Disentangling Effects on Dividends from Non-Deposit Debt of Short-Term}

We examine the composition of non-deposit liabilities, and test the effect on dividends from non-deposit debt of short-term duration. Indeed, the rolling-over of non-deposit short-term debt could limit the incentive to distribute dividends. (Note 13)

The variable SHORTTERM_NONDEP_TA calculates the ratio of short-term borrowings over total assets. It includes claims with a maturity of one year or less, and does not include repurchase agreements (repos). Instead, the variable REPOS_TA disentangles the value of repurchase agreements over total assets. In Table 10 the latter two variables are added in the equations for dividends. Both have positive estimated sign, although never statistically significant. The control for short-term non-deposit debt does not give further insights on the baseline results.

Table 10. The effect from short-term non-deposit leverage on banks' dividends

\begin{tabular}{cccc}
\hline & DIVIDEND_DUMMY & DIVIDEND_EARNINGS & DIVIDEND_EQUITY \\
& $(1)$ & $(2)$ & $(3)$ \\
\hline SHORTTERM_NONDEP_TA & -0.281 & 0.121 & 0.032 \\
& $(0.203)$ & $(1.155)$ & $(0.038)$ \\
REPOS_TA & 0.102 & 2.552 & 0.028 \\
Control Variables & $(0.174)$ & $(1.896)$ & $(0.038)$ \\
Firm and Time Effects & Yes & Yes & Yes \\
\hline Pseudo- $R^{2} / R^{2}$ (within) & Yes & Yes & Yes \\
Observations & 0.177 & 0.141 & 0.130 \\
\hline
\end{tabular}

Each column estimates regression models during the sample period 2008q4-2011q3. Column 1: Coefficients estimated by a Logit model for DIVIDEND_DUMMY. The set of regressors includes also the following variables, which are not reported in the table: SIZE, ROA, EQUITY_TA, CASH_TA, MTBV, LOANS_TA, RWA_TA, INCOME_TAX_TA, EMPL_COMP, CAPRATIO, and a set of dummies for banks and quarters. Standard errors are reported in parentheses. Column 2: Coefficients estimated by an Ordinary Least Squares (OLS) model for DIVIDEND_EARNINGS. The set of regressors includes also the following variables, which are not reported in the table: DIVIDEND_EARNINGS $(t-1)$, SIZE, ROA, EQUITY_TA, CASH_TA, MTBV, LOANS_TA, RWA_TA, INCOME_TAX_TA, EMPL_COMP, CAPRATIO, a constant, and a set of dummies for banks and quarters. DIVIDEND_EARNINGS is winsorized at the $1 \%$ and $99 \%$ level. Standard errors are clustered at the bank level and are reported in parentheses. Column 3: Coefficients estimated by an Ordinary Least Squares (OLS) model for DIVIDEND_EQUITY. The set of regressors includes also the following variables, which are not reported in the table: DIVIDEND_EQUITY (t-1), SIZE, ROA, EQUITY_TA, CASH_TA, MTBV, LOANS_TA, RWA_TA, INCOME_TAX_TA, EMPL_COMP, CAPRATIO, a constant, and a set of dummies for banks and quarters. DIVIDEND_EQUITY is winsorized at the $1 \%$ and $99 \%$ level. Standard errors are clustered at the bank level and are reported in parentheses. Significance: ${ }^{*} \mathrm{p}<0.10,{ }^{* *} \mathrm{p}<0.05,{ }^{* * *} \mathrm{p}<0.01$

\subsection{Estimates Including Controls for the Troubled Asset Relief Program (TARP) and Too-Big-To-Fail Status}

Some of the banks in the sample are involved by the Troubled Asset Relief Program (TARP) initiated from the United States Government starting from October 2008. The TARP Capital Purchase Program imposed to the participating banks some restrictions on dividends. More precisely, banks could neither pay nor increase their dividends before having made the other payments on the senior preferred stock held by the United States Department 
of Treasury (UST); while even when banks were allowed to pay dividends, they had to get the approval from the UST.

We now check to what extent the TARP has got influence on the estimated outcomes. In Table 11 we focus on the sub-period 2008q4-2011q3, and run similar regressions to (1) and (2), where we add controls for the TARP provision. Column 1 includes the amount of equity issued under the TARP normalized by total assets (TARPEQUITY_TA); column 2 includes a dichotomous variable denoting with value one whether the bank has received TARP equity (TARPEQUITY_DUMMY); finally, in column 3 NONDEPOSITS_TA is interacted with TARPEQUITY_DUMMY. Overall, the TARP impact is not remarkable, and the quality of our outcomes is not affected by the control for the TARP. For further robustness, in Table 12 we verify that no change in the main results occurs if we interact leverage with a dummy denoting with value one whether the bank is among the eight banks from the United States defined by the Financial Stability Board as "systemically important financial institutions." (Note 14)

Table 11. The effect from leverage on banks' dividends, controlling for equity issued under the Unite States Treasury's Troubled Asset Relief Program (TARP)

\begin{tabular}{cccccccccc}
\hline & \multicolumn{3}{c}{ DIVIDEND_DUMMY } & \multicolumn{3}{c}{ DIVIDEND_EARNINGS } & \multicolumn{3}{c}{ DIVIDEND_EQUITY } \\
& $(1)$ & $(2)$ & $(3)$ & $(4)$ & $(5)$ & $(6)$ & $(7)$ & $(8)$ & $(9)$ \\
\hline NONDEPOSITS_TA & $0.189^{* * *}$ & $0.175^{* *}$ & $0.250^{* * * *}$ & 1.076 & 1.095 & 1.099 & $0.048^{* * *}$ & $0.048^{* * *}$ & $0.040^{* * *}$ \\
& $(0.074)$ & $(0.075)$ & $(0.093)$ & $(0.734)$ & $(0.733)$ & $(0.818)$ & $(0.014)$ & $(0.014)$ & $(0.015)$ \\
TARPEQUITY_TA & $-1.176^{* * *}$ & & & -1.698 & & & 0.036 & & \\
& $(0.333)$ & & & $(3.250)$ & & & $(0.056)$ & & \\
TARPEQUITY_DUMMY & & $-3.090^{* * *}$ & -1.703 & & -4.976 & -4.868 & & 0.066 & -0.175 \\
NONDEPOSITS_TA & & $(0.927)$ & $(1.226)$ & & $(5.973)$ & $(13.087)$ & & $(0.128)$ & $(0.204)$ \\
TARPEQUITY_DUMMY & & & -0.140 & & & -0.009 & & 0.020 \\
Control Variables & Yes & Yes & Yes & Yes & Yes & Yes & Yes & Yes & Yes \\
Firm and Time Effects & Yes & Yes & Yes & Yes & Yes & Yes & Yes & Yes & Yes \\
\hline Pseudo- $R^{2} / R^{2}$ (within) & 0.209 & 0.209 & 0.214 & 0.150 & 0.150 & 0.150 & 0.142 & 0.142 & 0.143 \\
Observations & 578 & 578 & 578 & 2396 & 2396 & 2396 & 3933 & 3933 & 3933 \\
\hline
\end{tabular}

Each column estimates regression models during the sample period 2008q4-2011q3. Columns 1-3: Coefficients estimated by a Logit model for DIVIDEND_DUMMY. The set of regressors includes also the following variables, which are not reported in the table: SIZE, ROA, EQUITY_TA, CASH_TA, MTBV, LOANS_TA, RWA_TA, INCOME_TAX_TA, EMPL_COMP, CAPRATIO, and a set of dummies for banks and quarters. The three columns differ in the variable which controls for the effect from Treasury's Troubled Asset Relief Program (TARP). Standard errors are reported in parentheses. Columns 4-6: Coefficients estimated by an Ordinary Least Squares (OLS) model for DIVIDEND_EARNINGS. The set of regressors includes also the following variables, which are not reported in the table: DIVIDEND_EARNINGS (t-1), SIZE, ROA, EQUITY_TA, CASH_TA, MTBV, LOANS_TA, RWA_TA, INCOME_TAX_TA, EMPL_COMP, CAPRATIO, a constant, and a set of dummies for banks and quarters. DIVIDEND_EARNINGS is winsorized at the $1 \%$ and $99 \%$ level. The three columns differ in the variable which controls for the effect from Treasury's Troubled Asset Relief Program (TARP). Standard errors are clustered at the bank level and are reported in parentheses. Columns 7-9: Coefficients estimated by an Ordinary Least Squares (OLS) model for DIVIDEND_EQUITY. The set of regressors includes also the following variables, which are not reported in the table: DIVIDEND_EQUITY (t-1), SIZE, ROA, EQUITY_TA, CASH_TA, MTBV, LOANS_TA, RWA_TA, INCOME_TAX_TA, EMPL_COMP, CAPRATIO, a constant, and a set of dummies for banks and quarters. DIVIDEND_EQUITY is winsorized at the $1 \%$ and $99 \%$ level. The three columns differ in the variables which controls for the effect from Treasury's Troubled Asset Relief Program (TARP). Standard errors are clustered at the bank level and are reported in parentheses. Significance: ${ }^{*} \mathrm{p}<0.10,{ }^{* *} \mathrm{p}<0.05,{ }^{* * *} \mathrm{p}<0.01$ 
Table 12. The effect from leverage on banks' dividends, including the interaction between leverage and a dichotomous variable denoting "too-big-to-fail" institutions

\begin{tabular}{|c|c|c|c|c|c|c|}
\hline & \multicolumn{2}{|c|}{ DIVIDEND_DUMMY } & \multicolumn{2}{|c|}{ DIVIDEND_EARNINGS } & \multicolumn{2}{|c|}{ DIVIDEND_EQUITY } \\
\hline & (1) & (2) & (3) & (4) & (5) & (6) \\
\hline NONDEPOSITS_TA & $\begin{array}{l}0.142^{*} \\
(0.075)\end{array}$ & & $\begin{array}{l}1.060 \\
(0.731)\end{array}$ & & $\begin{array}{c}0.047^{* * * *} \\
(0.014)\end{array}$ & \\
\hline DEPOSITS_TA & & $\begin{array}{l}-0.170^{* *} \\
(0.075)\end{array}$ & & $\begin{array}{l}-1.359^{*} \\
(0.734)\end{array}$ & & $\begin{array}{c}-0.043^{* *} \\
(0.012)\end{array}$ \\
\hline $\begin{array}{l}\text { NONDEPOSITS_TA* } \\
\text { TOOBIGTF_DUMMY }\end{array}$ & $\begin{array}{l}-1.418 \\
(1.137)\end{array}$ & & $\begin{array}{l}-5.294^{* * *} \\
(0.100)\end{array}$ & & $\begin{array}{c}0.268 \\
(0.168)\end{array}$ & \\
\hline $\begin{array}{c}\text { DEPOSITS_TA* } \\
\text { TOOBIGTF_DUMMY }\end{array}$ & & $\begin{array}{c}0.204 \\
(0.359)\end{array}$ & & $\begin{array}{c}2.946 \\
(2.551)\end{array}$ & & $\begin{array}{l}-0.244 \\
(0.240)\end{array}$ \\
\hline Control Variables & Yes & Yes & Yes & Yes & Yes & Yes \\
\hline Firm and Time Effects & Yes & Yes & Yes & Yes & Yes & Yes \\
\hline Pseudo- $R^{2} / R^{2}$ (within) & 0.183 & 0.180 & 0.150 & 0.151 & 0.145 & 0.144 \\
\hline Observations & 578 & 521 & 2403 & 2403 & 3945 & 3945 \\
\hline
\end{tabular}

Each column estimates regression models during the sample period 2008q4-2011q3. TOOBIGTF_DUMMY is a dichotomous variable which assumes value one if the bank is classified as a "systemically important financial institution." The banks from the United States which the Financial Stability Board classifies (in November 2011) as "systemically important financial institutions" are the following: Bank of America, Bank of New York Mellon, Citigroup, Goldman Sachs, JPMorgan Chase, Morgan Stanley, State Street, Wells Fargo. Columns 1-2: Coefficients estimated by a Logit model for DIVIDEND_DUMMY. The set of regressors includes also the following variables, which are not reported in the table: SIZE, ROA, EQUITY_TA, CASH_TA, MTBV, LOANS_TA, RWA_TA, INCOME_TAX_TA, EMPL_COMP, CAPRATIO, and a set of dummies for banks and quarters. Standard errors are reported in parentheses. Columns 4-6: Coefficients estimated by an Ordinary Least Squares (OLS) model for DIVIDEND_EARNINGS. The set of regressors includes also the following variables, which are not reported in the table: DIVIDEND_EARNINGS (t-1), SIZE, ROA, EQUITY_TA, CASH_TA, MTBV, LOANS_TA, RWA_TA, INCOME_TAX_TA, EMPL_COMP, CAPRATIO, a constant, and a set of dummies for banks and quarters. DIVIDEND_EARNINGS is winsorized at the $1 \%$ and $99 \%$ level. Standard errors are clustered at the bank level and are reported in parentheses. Columns 7-9: Coefficients estimated by an Ordinary Least Squares (OLS) model for DIVIDEND_EQUITY. The set of regressors includes also the following variables, which are not reported in the table: DIVIDEND_EQUITY (t-1),SIZE, ROA, EQUITY_TA, CASH_TA, MTBV, LOANS_TA, RWA_TA, INCOME_TAX_TA, EMPL_COMP, CAPRATIO, a constant, and a set of dummies for banks and quarters. DIVIDEND_EQUITY is winsorized at the $1 \%$ and $99 \%$ level. Standard errors are clustered at the bank level and are reported in parentheses. Significance: ${ }^{*} \mathrm{p}<0.10,{ }^{* *} \mathrm{p}<0.05,{ }^{* * *} \mathrm{p}<0.01$

\section{Tests for the Robustness of the Econometric Modeling}

We check that the results we obtain in the previous sections are robust to different econometric approaches. We acknowledge that there might be endogeneity involving our outcomes. Although we cannot entirely overcome the endogeneity issue, we want to quantify the impact from leverage on dividends using several other approaches, so to corroborate the claim that our major results and their interpretation are not severely spoiled by endogeneity. 


\subsection{Simultaneous Systems of Equations}

We estimate a bivariate system of equations modeling the simultaneous choice on dividends and leverage:

$$
\begin{aligned}
& \text { DIVIDEND_EQUITY } Y_{i, t} \\
& =\alpha_{0}+\alpha_{1} \text { DIVIDEND_EQUITY }_{i,(t-1)}+\alpha_{2} \text { LEVERAGE }_{d, i, t}+\alpha_{3} \operatorname{SIZE}_{i, t}+\alpha_{4} R O A_{i, t} \\
& +\alpha_{5} E Q U I T Y_{-} T A_{i, t}+\alpha_{6} C_{A S H} T A_{i, t}+\alpha_{7} M T B V_{i, t}+\alpha_{8} L O A N S_{-} T A_{i, t}+\alpha_{9} R W A_{-} T A_{i, t}
\end{aligned}
$$

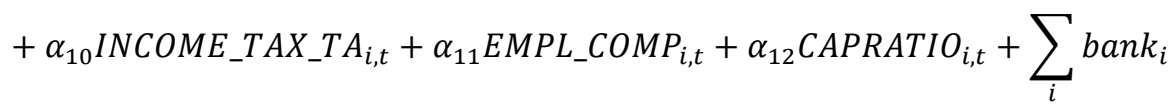

$$
\begin{aligned}
& +\sum_{t} \text { quarter }_{t}+\varepsilon_{i, t} \\
& \text { LEVERAGE }_{d, i, t}=\alpha_{0}+\alpha_{1} \text { DIVIDEND_EQUITY }_{i, t}+\alpha_{2} \operatorname{SIZE}_{i, t}+\alpha_{3} \text { ROA }_{i, t}+\alpha_{4} \text { MTBV }_{i, t}+\sum_{i} b{ } k_{i} \\
& +\sum_{t} \text { quarter }_{t}+\vartheta_{i, t}
\end{aligned}
$$

Where $d=$ DEP\&NONDEP_TA,NONDEPOSITS_TA,DEPOSITS_TA

In the dividend equation the dependent variable is the dividend payout as captured by DIVIDEND_EQUITY. We separate the sample into two time horizons, namely 2000q1-2008q2, and 2008q3-2011q3. The set of covariates in the dividend equation stays the same as in equation (2). The regressors in the leverage equation are dividends, size, profitability, and investment opportunities. Gropp and Heider (2010) use similar regressors for the explanation of banks' book and market leverage. We include quarter and firm dummies, and fit each system of equation following the approach implemented by Zellner (1962), Zellner and Huang (1962), and Zellner (1963). (Note 15)

\begin{tabular}{|c|c|c|c|c|c|c|}
\hline \multirow{2}{*}{ Panel A (2000q1-2008q3) } & DIVIDEND_EQUITY & $D E P \& N O N D E P \_T A$ & DIVIDEND_EQUITY & NONDEPOSITS_TA & DIVIDEND_EQUITY & DEPOSITS_TA \\
\hline & (1) & (2) & (3) & (4) & (5) & (6) \\
\hline \multirow{2}{*}{ DIVIDEND_EQUITY } & & $0.000^{* *}$ & & 0.024 & & -0.001 \\
\hline & & $(0.000)$ & & $(0.021)$ & & $(0.022)$ \\
\hline \multirow{2}{*}{ DIVIDEND_EQUITY(t-1) } & $-0.077^{* * *}$ & & $-0.077^{* * * *}$ & & $-0.077^{* * * *}$ & \\
\hline & $(0.009)$ & & $(0.009)$ & & $(0.009)$ & \\
\hline \multirow{2}{*}{ DEP\&NONDEP_TA } & -2.716 & & & & & \\
\hline & $(2.108)$ & & & & & \\
\hline \multirow{2}{*}{ NONDEPOSITS_TA } & & & 0.004 & & & \\
\hline & & & $(0.007)$ & & & \\
\hline \multirow{2}{*}{ DEPOSITS_TA } & & & & & -0.004 & \\
\hline & & & & & $(0.007)$ & \\
\hline \multirow{2}{*}{ SIZE } & -0.162 & $0.014^{* * *}$ & -0.158 & $5.241^{* * *}$ & -0.156 & $-3.866^{* * *}$ \\
\hline & $(0.141)$ & $(0.001)$ & $(0.144)$ & $(0.246)$ & $(0.143)$ & $(0.261)$ \\
\hline
\end{tabular}

Table 13 displays the results. Again, the crisis window reveals the most interesting patterns, where the Breusch-Pagan test rejects the null hypothesis that the two equations are independent. The systems of equations confirm the opposite signs on deposits versus non-deposits which we got in the previous univariate regressions.

Table 13. Simultaneous system of equations for banks' dividends and leverage 


\begin{tabular}{|c|c|c|c|c|c|c|}
\hline$R O A$ & $\begin{array}{c}0.035 \\
(0.032)\end{array}$ & $\begin{array}{c}0.003^{* * * *} \\
(0.000)\end{array}$ & $\begin{array}{c}0.041 \\
(0.032)\end{array}$ & $\begin{array}{c}0.377^{* * *} \\
(0.057)\end{array}$ & $\begin{array}{c}0.041 \\
(0.032)\end{array}$ & $\begin{array}{c}0.632^{* * *} \\
(0.060)\end{array}$ \\
\hline EQUITY_TA & $\begin{array}{c}0.083^{* * *} \\
(0.029)\end{array}$ & & $\begin{array}{l}0.046^{* *} \\
(0.021)\end{array}$ & & $\begin{array}{l}0.047^{* *} \\
(0.021)\end{array}$ & \\
\hline CASH_TA & $\begin{array}{l}-0.009 \\
(0.008)\end{array}$ & & $\begin{array}{l}-0.010 \\
(0.008)\end{array}$ & & $\begin{array}{l}-0.009 \\
(0.009)\end{array}$ & \\
\hline$M T B V$ & $\begin{array}{c}0.005^{* * *} \\
(0.001)\end{array}$ & $\begin{array}{c}0.000^{* * *} \\
(0.000)\end{array}$ & $\begin{array}{c}0.005^{* * *} \\
(0.001)\end{array}$ & $\begin{array}{c}0.001 \\
(0.001)\end{array}$ & $\begin{array}{c}0.005^{* * *} \\
(0.001)\end{array}$ & $\begin{array}{c}0.005^{* * *} \\
(0.001)\end{array}$ \\
\hline LOANS_TA & $\begin{array}{c}-0.015^{* *} \\
(0.008)\end{array}$ & & $\begin{array}{c}-0.017^{* *} \\
(0.007)\end{array}$ & & $\begin{array}{c}-0.016^{* *} \\
(0.008)\end{array}$ & \\
\hline$R W A \_T A$ & $\begin{array}{c}0.013 \\
(0.008)\end{array}$ & & $\begin{array}{l}0.014^{*} \\
(0.008)\end{array}$ & & $\begin{array}{l}0.015^{*} \\
(0.008)\end{array}$ & \\
\hline INCOME_TAX_TA & $\begin{array}{l}-0.002 \\
(0.095)\end{array}$ & & $\begin{array}{l}-0.002 \\
(0.095)\end{array}$ & & $\begin{array}{l}-0.003 \\
(0.095)\end{array}$ & \\
\hline$E M P L \_C O M P$ & $\begin{array}{l}-0.004 \\
(0.003)\end{array}$ & & $\begin{array}{l}-0.004 \\
(0.003)\end{array}$ & & $\begin{array}{l}-0.004 \\
(0.003)\end{array}$ & \\
\hline CAPRATIO & $\begin{array}{c}0.006 \\
(0.012)\end{array}$ & & $\begin{array}{c}0.006 \\
(0.012)\end{array}$ & & $\begin{array}{c}0.005 \\
(0.012)\end{array}$ & \\
\hline Firm and Time Effects & Yes & Yes & Yes & Yes & Yes & Yes \\
\hline$R^{2}$ & 0.725 & 0.866 & 0.725 & 0.866 & 0.725 & 0.866 \\
\hline Observations & 7382 & 7382 & 7382 & 7382 & 7387 & 7387 \\
\hline Breusch-Pagan Test $(\chi 2)$ & 1.121 & & 0.324 & & 0.000 & \\
\hline
\end{tabular}

\begin{tabular}{|c|c|c|c|c|c|c|}
\hline Panel B (2008q4-2011q3) & $\begin{array}{c}\text { DIVIDEND_EQUITY } \\
\text { (1) }\end{array}$ & $\begin{array}{c}D E P \& N O N D E P_{-} T A \\
\text { (2) }\end{array}$ & $\begin{array}{c}\text { DIVIDEND_EQUITY } \\
\text { (3) }\end{array}$ & $\begin{array}{c}\text { NONDEPOSITS_TA } \\
\text { (4) }\end{array}$ & $\begin{array}{c}\text { DIVIDEND_EQUITY } \\
\text { (5) }\end{array}$ & $\begin{array}{c}\text { DEPOSITS_TA } \\
\text { (6) }\end{array}$ \\
\hline DIVIDEND_EQUITY & & $\begin{array}{l}0.000^{*} \\
(0.000)\end{array}$ & & $\begin{array}{l}0.208^{* * *} \\
(0.026)\end{array}$ & & $\begin{array}{l}-0.172^{* * *} \\
(0.031)\end{array}$ \\
\hline DIVIDEND_EQUITY(t-1) & $\begin{array}{l}0.009 \\
(0.010)\end{array}$ & & $\begin{array}{l}0.007 \\
(0.010)\end{array}$ & & $\begin{array}{l}0.007 \\
(0.010)\end{array}$ & \\
\hline$D E P \& N O N D E P \_T A$ & $\begin{array}{l}-1.098 \\
(1.731)\end{array}$ & & & & & \\
\hline NONDEPOSITS_TA & & & $\begin{array}{l}0.087^{* * *} \\
(0.010)\end{array}$ & & & \\
\hline DEPOSITS_TA & & & & & $\begin{array}{l}-0.065^{\text {*** }} \\
(0.009)\end{array}$ & \\
\hline SIZE & $\begin{array}{l}0.924^{* * *} \\
(0.260)\end{array}$ & $\begin{array}{l}0.019^{* * *} \\
(0.003)\end{array}$ & $\begin{array}{l}1.014^{* * *} \\
(0.258)\end{array}$ & $\begin{array}{l}-0.170 \\
(0.379)\end{array}$ & $\begin{array}{l}1.007^{* * *} \\
(0.258)\end{array}$ & $\begin{array}{l}2.092^{* * *} \\
(0.457)\end{array}$ \\
\hline$R O A$ & $\begin{array}{l}0.039^{* * *} \\
(0.011)\end{array}$ & $\begin{array}{l}-0.001^{* * *} \\
(0.000)\end{array}$ & $\begin{array}{l}0.040^{* * *} \\
(0.011)\end{array}$ & $\begin{array}{l}-0.024 \\
(0.018)\end{array}$ & $\begin{array}{l}0.037^{* * *} \\
(0.011)\end{array}$ & $\begin{array}{l}-0.056^{* * *} \\
(0.021)\end{array}$ \\
\hline EQUITY_TA & $\begin{array}{l}0.018 \\
(0.038)\end{array}$ & & $\begin{array}{l}0.061^{*} \\
(0.035)\end{array}$ & & $\begin{array}{l}0.020 \\
(0.035)\end{array}$ & \\
\hline CASH_TA & $\begin{array}{l}0.030^{* * * *} \\
(0.009)\end{array}$ & & $\begin{array}{l}0.035^{* * *} \\
(0.009)\end{array}$ & & $\begin{array}{l}0.036^{* * *} \\
(0.009)\end{array}$ & \\
\hline$M T B V$ & $0.007^{* * *}$ & $0.000^{*}$ & $0.007^{* * *}$ & -0.001 & $0.007^{* * *}$ & $0.003^{* *}$ \\
\hline
\end{tabular}




\begin{tabular}{|c|c|c|c|c|c|c|}
\hline & $(0.001)$ & $(0.000)$ & $(0.001)$ & $(0.001)$ & $(0.001)$ & $(0.002)$ \\
\hline \multirow{2}{*}{ LOANS_TA } & 0.015 & & 0.014 & & $0.019^{* *}$ & \\
\hline & $(0.010)$ & & $(0.009)$ & & $(0.010)$ & \\
\hline \multirow{2}{*}{$R W A \_T A$} & 0.004 & & 0.005 & & 0.002 & \\
\hline & $(0.011)$ & & $(0.011)$ & & $(0.011)$ & \\
\hline \multirow{2}{*}{ INCOME_TAX_TA } & $0.402^{* *}$ & & $0.356^{* *}$ & & $0.393^{* *}$ & \\
\hline & $(0.181)$ & & $(0.179)$ & & $(0.179)$ & \\
\hline \multirow{2}{*}{$E M P L \_C O M P$} & 0.001 & & 0.001 & & 0.002 & \\
\hline & $(0.003)$ & & $(0.003)$ & & $(0.003)$ & \\
\hline \multirow{2}{*}{ CAPRATIO } & $-0.056^{* *}$ & & $-0.064^{* *}$ & & $-0.065^{* *}$ & \\
\hline & $(0.026)$ & & $(0.026)$ & & $(0.026)$ & \\
\hline Firm and Time Effects & Yes & Yes & Yes & Yes & Yes & Yes \\
\hline$R^{2}$ & 0.783 & 0.860 & 0.783 & 0.925 & 0.784 & 0.915 \\
\hline Observations & 3857 & 3857 & 3857 & 3857 & 3857 & 3857 \\
\hline Breusch-Pagan Test $\left(\chi_{2}\right)$ & 0.710 & & $16.682^{* * * *}$ & & $7.796^{* * *}$ & \\
\hline
\end{tabular}

Panel A and B estimate the simultaneous system of equations in (3) on the two sample periods 2000q1-2008q3, and 2008q4-2011q3, respectively. On each panel, Columns 1,3, and 5 report the coefficients estimated on the equation for DIVIDEND_EQUITY. Columns 2, 4, and 6 report the coefficients estimated on the equation for leverage, which is measured, alternatively, by DEP\&NONDEP_TA, NONDEPOSITS_TA, and DEPOSITS_TA. The estimation is performed according to the one-way random effect estimation of seemingly-unrelated regressions implemented by Nguyen (2010).

\subsection{Use of Lagged Values of Leverage}

One further way to attenuate the endogeneity concern on our outcomes is to use lags of the leverage variables in the equations (1) and (2). When the bank decides on the dividend at time $t$, the balance sheet from the previous point in time cannot be modified. We regress the dividends at time $t$ on leverage computed at time $t-1$.

In Table 14 the first lag and the second lag of NONDEPOSITS_TA and DEPOSITS_TA replace the corresponding contemporaneous values in (1) and (2). The quality of the results is similar in sign and magnitude to the regressions where we used the contemporaneous variables. We acknowledge that the use of lagged regressors is one modest way for addressing the issue of endogeneity. On this purpose, in the next sub-section we employ another methodology, so to stress deeply the quality of the results.

Table 14. The effect from leverage on banks' dividends, including lagged values of leverage

\begin{tabular}{|c|c|c|c|c|c|c|c|c|c|c|c|c|}
\hline & \multicolumn{4}{|c|}{ DIVIDEND_DUMMY } & \multicolumn{4}{|c|}{ DIVIDEND_EARNINGS } & \multicolumn{4}{|c|}{ DIVIDEND_EQUITY } \\
\hline & (1) & (2) & (3) & (4) & (5) & $(6)$ & $(7)$ & (8) & $(9)$ & $(10)$ & $(11)$ & (12) \\
\hline \multirow{2}{*}{ NONDEPOSITS_TA $(t-1)$} & 0.102 & & & & 0.869 & & & & $0.039^{* * * *}$ & & & \\
\hline & $(0.064)$ & & & & $(0.576)$ & & & & $(0.014)$ & & & \\
\hline \multirow{2}{*}{ NONDEPOSITS_TA $(t-2)$} & & 0.080 & & & & $1.296^{* *}$ & & & & $0.026^{* *}$ & & \\
\hline & & $(0.058)$ & & & & $(0.635)$ & & & & $(0.013)$ & & \\
\hline \multirow{2}{*}{ DEPOSITS_TA $(t-1)$} & & & $-0.412^{* *}$ & & & & $-1.026^{*}$ & & & & $-0.036^{* * *}$ & \\
\hline & & & $(0.062)$ & & & & $(0.569)$ & & & & $(0.011)$ & \\
\hline \multirow{2}{*}{$D E P O S I T S \_T A(t-2)$} & & & & $-0.097^{*}$ & & & & $-1.222^{* *}$ & & & & $-0.020^{* *}$ \\
\hline & & & & $(0.055)$ & & & & $(0.592)$ & & & & $(0.009)$ \\
\hline Control Variables & Yes & Yes & Yes & Yes & Yes & Yes & Yes & Yes & Yes & Yes & Yes & Yes \\
\hline Firm and Time Effects & Yes & Yes & Yes & Yes & Yes & Yes & Yes & Yes & Yes & Yes & Yes & Yes \\
\hline Pseudo- $R^{2} / R^{2}$ (within) & 0.173 & 0.172 & 0.180 & 0.175 & 0.149 & 0.151 & 0.151 & 0.151 & 0.141 & 0.139 & 0.141 & 0.139 \\
\hline Observations & 578 & 578 & 578 & 578 & 2403 & 2402 & 2402 & 2400 & 3945 & 3940 & 3944 & 3941 \\
\hline
\end{tabular}


Each column estimates regression models during the sample period 2008q4-2011q3. Columns 1-4: Coefficients estimated by a Logit model for DIVIDEND_DUMMY. The set of regressors includes also the following variables, which are not reported in the table: SIZE, ROA, EQUITY_TA, CASH_TA, MTBV, LOANS_TA, RWA_TA, INCOME_TAX_TA, EMPL_COMP, CAPRATIO, and a set of dummies for banks and quarters. Standard errors are reported in parentheses. Columns 5-8: Coefficients estimated by an Ordinary Least Squares (OLS) model for DIVIDEND_EARNINGS. The set of regressors includes also the following variables, which are not reported in the table: DIVIDEND_EARNINGS (t-1), SIZE, ROA, EQUITY_TA, CASH_TA, MTBV, LOANS_TA, RWA_TA, INCOME_TAX_TA, EMPL_COMP, CAPRATIO, a constant, and a set of dummies for banks and quarters. DIVIDEND_EARNINGS is winsorized at the $1 \%$ and $99 \%$. Standard errors are clustered at the bank level and are reported in parentheses. Columns 9-12: Coefficients estimated by an Ordinary Least Squares (OLS) model for DIVIDEND_EQUITY. The set of regressors includes also the following variables, which are not reported in the table: DIVIDEND_EQUITY (t-1),SIZE, ROA, EQUITY_TA, CASH_TA, MTBV, LOANS_TA, RWA_TA, INCOME_TAX_TA, $E M P L \_C O M P, C A P R A T I O$, a constant, and a set of dummies for banks and quarters. DIVIDEND_EQUITY is winsorized at the $1 \%$ and $99 \%$ level. Standard errors are clustered at the bank level and are reported in parentheses. Significance: ${ }^{*} \mathrm{p}<0.10,{ }^{* *} \mathrm{p}<0.05,{ }^{* * *} \mathrm{p}<0.01$

\subsection{Regressions with Instrumental Variables}

This sub-section implements instrumental variable (IV) regressions. More precisely, we estimate the models for the two payout measures and for DIVIDEND_DUMMY instrumenting the regressor DEPOSITS_AS, which we suspect to be endogenous. For this task, we obtain from our data-source information on the interest paid by banks on their interest-bearing deposits. We call INTEREST_DEPOSITS the ratio of the interest incurred on deposits as a percent of average deposits, and use it as instrument for DEPOSITS_AS. Thus, INTEREST_DEPOSITS approximates the average interest rate paid on deposits. We assume that the ultimate decision on how much to pay to owners out of the current equity or earnings, is not substantially related to the interest earned by depositors on their money. As mentioned in the previous sub-section 5.1, and as reported in Table 8, our banks collect large amounts of current accounts and retail time deposits, which typically yield low returns. To our view, it is reasonable to think that while the average interest on deposits is correlated to the level of deposit leverage, the same interest on deposits is not an important driver for the bank's choice on dividends.

Table 15 displays results from IV-GMM regressions during the turmoil period. In the first stage regression, DEPOSITS_AS has got positive sign on INTEREST_DEPOSITS. In the second stage regression, the instrumented deposit leverage has got negative sign on DIVIDEND_DUMMY and DIVIDEND_EQUITY. The choice of our instrument is not rejected by diagnostic checks. (Note 16) We conclude that the approach of IV regressions supports the quality of the previous outcomes.

Table 15. The effect from deposit leverage on banks' dividends: Output from Instrumental Variables (IV) regressions

\begin{tabular}{|c|c|c|c|c|c|c|}
\hline & $\begin{array}{c}\text { First Stage } \\
\text { DEPOSITS_TA }\end{array}$ & $\begin{array}{c}\text { Second Stage } \\
\text { DIVIDEND_EARNINGS }\end{array}$ & $\begin{array}{c}\text { First Stage } \\
\text { DEPOSITS_TA }\end{array}$ & $\begin{array}{c}\text { Second Stage } \\
\text { DIVIDEND_EQUITY }\end{array}$ & $\begin{array}{c}\text { First Stage } \\
\text { DEPOSITS_TA }\end{array}$ & $\begin{array}{c}\text { Second Stage } \\
\text { DIVIDEND_DUMMY }\end{array}$ \\
\hline \multirow[t]{2}{*}{ DEPOSITS_AS } & - & 3.512 & - & $-0.863^{* *}$ & - & $-0.318^{* * *}$ \\
\hline & & $(5.266)$ & & $(0.356)$ & & $(0.044)$ \\
\hline \multicolumn{7}{|l|}{ Instrument: } \\
\hline \multirow[t]{2}{*}{ INTEREST_DEPOSITS } & $0.770^{* * *}$ & - & $0.703^{* * *}$ & - & $1.471^{* * *}$ & - \\
\hline & $(0.252)$ & & $(0.256)$ & & $(0.198)$ & \\
\hline Observations & 6736 & 6736 & 9782 & 9782 & 6778 & 6778 \\
\hline Anderson-Rubin Wald & 0.460 & - & $33.180^{* * *}$ & - & - & - \\
\hline Cragg-Donald Wald $F$ & - & 18.264 & - & 17.844 & - & - \\
\hline Wald test for & - & - & - & - & $139.320^{* * *}$ & \\
\hline Critical Values for & $10 \%$ max size & 16.38 & & & & \\
\hline Cragg-Donald Wald F & $15 \%$ max size & 8.96 & & & & \\
\hline \multirow[t]{2}{*}{ Statistic } & $20 \%$ max size & 6.66 & & & & \\
\hline & $25 \%$ max size & 5.53 & & & & \\
\hline
\end{tabular}


The table shows estimates from Instrumental Variables (IV) regressions, where DEPOSITS_TA is instrumented by INTEREST_DEPOSITS. In the equations for DIVIDEND_EARNINGS and DIVIDEND_EQUITY the coefficients are estimated using the two-step efficient Generalized Method of Moments (GMM) estimator; in the equation for DIVIDEND_DUMMY coefficients are estimated using the Newey's minimum chi-squared estimator. The sample period is 2008q4-2011q3. Both DIVIDEND_EARNINGS and DIVIDEND_EQUITY are winsorized at the 1\% and $99 \%$ level. Robust standard errors are reported in parentheses. The critical values for the Cragg-Donald Wald $F$ Statistic are taken by Stock and Yogo (2005). ${ }^{*} \mathrm{p}<0.10, * * \mathrm{p}<0.05, * * * \mathrm{p}<0.0$

\subsection{Alternative Estimation Methods for the Dividend Payout}

\subsubsection{Dynamic Panel Data (DPD) Models}

The dividend payout in (1) is now modeled according to a dynamic panel data (DPD) model. In the context of DPD the estimation of fixed effects models is a difficult issue, especially in the case of panels with a large number of units and few periods. Nickell (1981) shows that the presence of the lagged dependent variable determines a bias in the coefficients estimated on both the lagged dependent variable as well as on other regressors. Arellano and Bond (1991) popularized the work from Holtz-Eakin, Newey and Rosen (1988) and propose a method offering more efficient estimates of DPD models which is based on a Generalized Method of Moments (GMM) approach.

Table 16 (columns 3-4) estimates the effect from deposit leverage on the dividend payout using the procedure of Arellano and Bond (1991). Similar results arise when we implement the modified estimator (system GMM) of Arellano and Bover (1995) and Blundell and Bond (1998). (Note 17) After employing techniques which take into account of the dynamic structure of the payout equation, we still find that deposit leverage has got negative and significant sign on dividends.

Table 16. The effect from deposit leverage on banks’' dividends: Output from Tobit Model, and Dynamic Panel Data Model

\begin{tabular}{|c|c|c|c|c|}
\hline & \multicolumn{2}{|c|}{ Honoré (1992) } & \multicolumn{2}{|c|}{ Arellano and Bond (1991) } \\
\hline & $\begin{array}{c}\text { DIVIDEND_EARNINGS } \\
(1)\end{array}$ & $\begin{array}{c}\text { DIVIDEND_EQUITY } \\
(2)\end{array}$ & $\begin{array}{c}\text { DIVIDEND_EARNINGS } \\
\text { (3) }\end{array}$ & $\begin{array}{c}\text { DIVIDEND_EQUITY } \\
\text { (4) }\end{array}$ \\
\hline \multirow{2}{*}{ Dependent variable $(t-1)$} & -0.015 & $-0.186^{* *}$ & -0.062 & $-0.220^{* * *}$ \\
\hline & $(0.057)$ & $(0.078)$ & $(0.050)$ & $(0.070)$ \\
\hline \multirow{2}{*}{ DEPOSITS_TA } & $-2.142^{* *}$ & $-0.079^{* *}$ & $-1.863^{* *}$ & $-0.137^{* * * *}$ \\
\hline & $(1.041)$ & $(0.033)$ & $(0.732)$ & $(0.019)$ \\
\hline \multirow{2}{*}{ SIZE } & $83.816^{* * *}$ & $3.885^{* * *}$ & -10.084 & 0.077 \\
\hline & $(34.081)$ & $(0.714)$ & $(25.861)$ & $(0.522)$ \\
\hline \multirow{2}{*}{$R O A$} & $-127.438^{* * *}$ & $0.075^{*}$ & $-31.218^{* * *}$ & $0.046^{* * *}$ \\
\hline & $(17.593)$ & $(0.042)$ & $(5.009)$ & $(0.013)$ \\
\hline \multirow{2}{*}{$E Q U I T Y \_T A$} & 3.944 & 0.025 & $-9.314^{* *}$ & -0.064 \\
\hline & $(6.138)$ & $(0.124)$ & $(3.866)$ & $(0.061)$ \\
\hline \multirow{2}{*}{$C A S H \_T A$} & 1.553 & $0.060^{* * *}$ & 0.231 & $0.080^{* * * *}$ \\
\hline & $(1.060)$ & $(0.028)$ & $(0.685)$ & $(0.025)$ \\
\hline \multirow{2}{*}{$M T B V$} & $0.261^{* * *}$ & $0.017^{* * *}$ & $-0.111^{*}$ & $0.009^{* * *}$ \\
\hline & $(0.098)$ & $(0.003)$ & $(0.065)$ & $(0.002)$ \\
\hline \multirow{2}{*}{$L O A N S \_T A$} & -0.303 & 0.035 & $-3.312^{* * *}$ & $0.109^{* * *}$ \\
\hline & $(0.847)$ & $(0.023)$ & $(1.081)$ & $(0.023)$ \\
\hline \multirow{2}{*}{$R W A \_T A$} & $1.999^{* *}$ & 0.037 & $3.023^{* * *}$ & -0.008 \\
\hline & $(0.913)$ & $(0.029)$ & $(1.137)$ & $(0.025)$ \\
\hline \multirow{2}{*}{ INCOME_TAX_TA } & 25.131 & $1.126^{* *}$ & 1.559 & 0.300 \\
\hline & $(15.729)$ & $(0.515)$ & $(7.836)$ & $(0.233)$ \\
\hline \multirow{2}{*}{$E M P L \_C O M P$} & -0.156 & -0.003 & $0.516^{* * * *}$ & $-0.008^{*}$ \\
\hline & $(0.402)$ & $(0.010)$ & $(0.196)$ & $(0.005)$ \\
\hline \multirow{2}{*}{ CAPRATIO } & -0.820 & -0.057 & 0.008 & $-0.091^{* *}$ \\
\hline & (3.362) & $(0.091)$ & (2.113) & $(0.045)$ \\
\hline Firm Effects & Yes & Yes & Yes & Yes \\
\hline
\end{tabular}




\begin{tabular}{ccccc} 
Time Effects & Yes & Yes & No & No \\
\hline$\chi^{2}$ & $192.010^{* * *}$ & $285.090^{* * * *}$ & $80.840^{* * *}$ & $113.860^{* * *}$ \\
Observations & 2403 & 3945 & 1958 & 3615 \\
\hline
\end{tabular}

Columns 1-2: Coefficients estimated by a Tobit model during the sample period 2008q4-2011q3. The estimation follows the technique of Honore (1992). Both DIVIDEND_EARNINGS and DIVIDEND_EQUITY are winsorized at the $1 \%$ and $99 \%$ level. Standard errors are estimated by the bootstrap, and are reported in parentheses. Columns 3-4: Coefficients estimated according to the method for dynamic panel data developed by Arellano and Bond (1991). Both DIVIDEND_EARNINGS and DIVIDEND_EQUITY are winsorized at the $1 \%$ and $99 \%$ level. Robust standard errors are reported in parentheses. Significance: ${ }^{*} \mathrm{p}<0.10,{ }^{* *} \mathrm{p}<0.05,{ }^{* * *} \mathrm{p}<0.01$

\subsubsection{Tobit Model}

In this final test, the dividend payout follows a corner solution model, which we estimate with a censored normal regression, or Tobit model. See Wooldridge (2010) for the estimation procedure of Tobit models. Indeed, for some banks the optimal payout coincides with the corner solution of zero dividends. The use of Tobit models on Panel data though, presents some issues. In the estimation of censored regression models with fixed effects, there is no sufficient statistic allowing the fixed effects to be conditioned out of the likelihood. Therefore, we implement the approach of Honoré (1992), which is based on a semiparametric estimator for fixed-effects Tobit models.

Table 16 above (columns 1-2) presents the results, where estimators are based on the absolute error loss function, and the standard errors are estimated by the bootstrap. The Tobit specification estimated following Honore (1992) discovers outcomes consistent with the ones from the OLS regressions, since deposit leverage continues to have a substantial decreasing impact on the dividend payout.

\section{Share Repurchases}

\subsection{Share Repurchases in the Sample}

We conclude the paper with a short analysis on the share repurchases inside our banks. Together with dividends, the repurchase of shares is another way for firms to divert resources to owners. For a literature on the topic of share repurchases we send to Allen and Michaely (2003).

We define REPURCHASE_DUMMY as a dichotomous variable assuming value one if the bank has bought-back some of its stock during the quarter. The relative repurchase payout is defined as the ratio of the common stock repurchased over net income (REPURCHASE_INCOME), as reported from the quarter cash flow statement. Table 17 reports descriptive statistics. Almost the $29 \%$ of the banks has re-acquired stock, thus less than half of the banks paying dividends, which are almost $65 \%$. The average repurchase payout is $19 \%$, and is highly volatile.

Table 17. Variables for banks's share repurchases

\begin{tabular}{cccccccc}
\hline Variable & Mean & Median & $5 \%$ & $25 \%$ & $75 \%$ & $95 \%$ & Std. Dev \\
\hline REPURCHASE_DUMMY & 28.816 & 0.000 & 0.000 & 0.000 & 100 & 100 & 0.453 \\
REPURCHASE_INCOME & 19.080 & 0.000 & 0.000 & 0.000 & 1.079 & 63.704 & 547.725 \\
\hline
\end{tabular}

The table reports the average value of the variables during the sample period 2000q1-2011q3.

Figure 2 compares the payout through repurchases to the payout through dividends. It is interesting to note that during the crisis of 2007-2009, the average payout through repurchases has decreased, while the dividend payout has increased. (Note 18) 


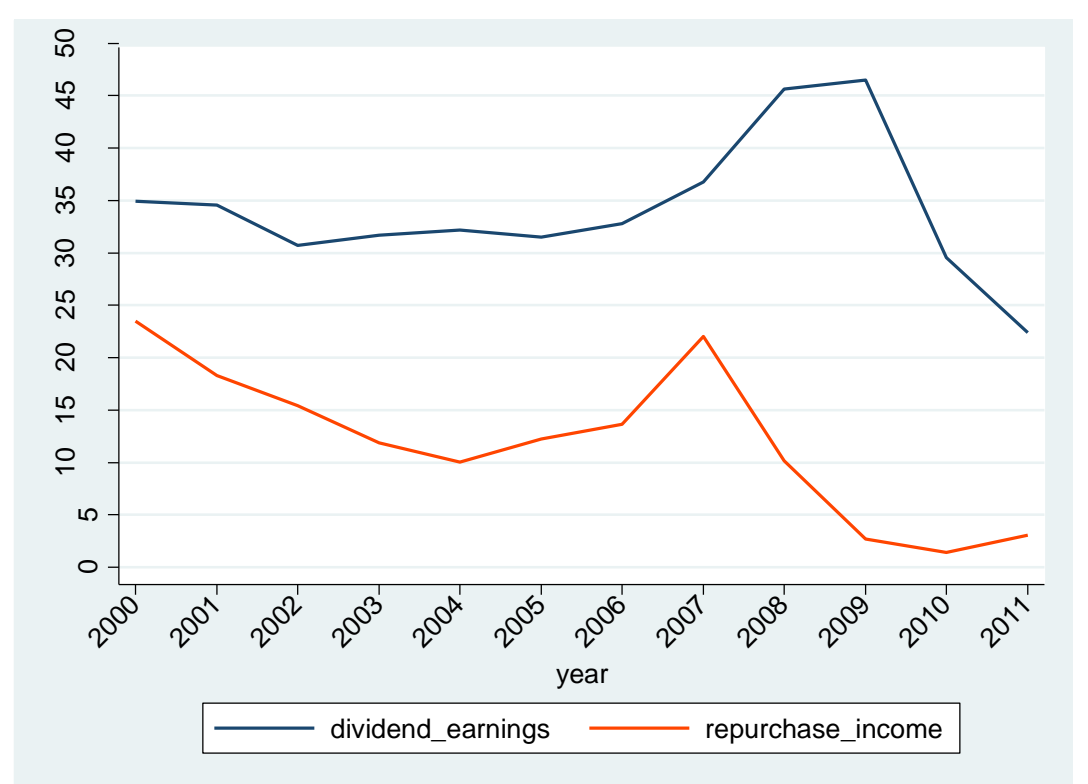

Figure 2. Payout through share repurchases and payout through dividends across years

The figure shows the variables DIVIDEND_EARNINGS and REPURCHASE_INCOME during 2000-2011.

DIVIDEND_EARNINGS and REPURCHASE_INCOME are winsorized at the $1 \%$ and $99 \%$ level.

Overall, our banks have paid out more cash through dividends, rather than repurchasing shares. This evidence is consistent with several studies affirming that firms have got a preference for dividends. For example, Bhargava (2010) says that firms which pay regular dividends are reluctant to lower their dividends for repurchasing shares, because they don't want to send ambiguous signals to investors. According to Ofer and Thakor (1987), due to high signaling costs, companies want to repurchase stock only when their equity is undervalued. Other papers discussing the relationship between dividends and share repurchases inlcude, Barclay and Smith (1988), Brennan and Thakor (1990), and Allen, Bernardo, and Welch (2000), and Allen and Michaely (2003).

We mention two more aspects which contribute to explain the larger use of dividends as compared to repurchases. These facts can further help to understand the evidence of Figure 2, where repurchases decline after the crisis. First, dividends are typically more flexible to adjust than repurchases. Second, repurchases can be sensitive to employees' stock options plans. When stock prices are high, employees find convenient to exercise their stock options, even though the current value of the stock get diluted. However, if the firm repurchases equity, the dilution can be off-set (see, among others, Kahle (2002) and Bens et al. (2003)). During the recent crisis, the stock prices of banks dropped, and bankers had no incentive to exercise high-strike options. Fahlenbrach and Stulz (2011) show that during the crisis banks' CEOs suffered losses on their shares and stock-options.

\subsection{Effects from Leverage on Share Repurchases}

We estimate how share repurchases change with banks' leverage. Models similar to (1) and (2) are now run for REPURCHASE_DUMMY and REPURCHASE_INCOME during 2008q4-2011q3. Table 18 reports the results. Only REPURCHASE_DUMMY reacts significantly to leverage. More precisely, banks are more likely to buy back shares when they have higher non-deposit leverage. The coefficients on the repurchase payout instead are never significant, although the estimated coefficients on the leverage components have the same signs that we have often commented in the previous analysis of dividends: while deposit leverage moves in the opposite way of share repurchases, the non-deposit leverage is positively correlated to share repurchases. 
Table 18. The effect from leverage on banks's share repurchases

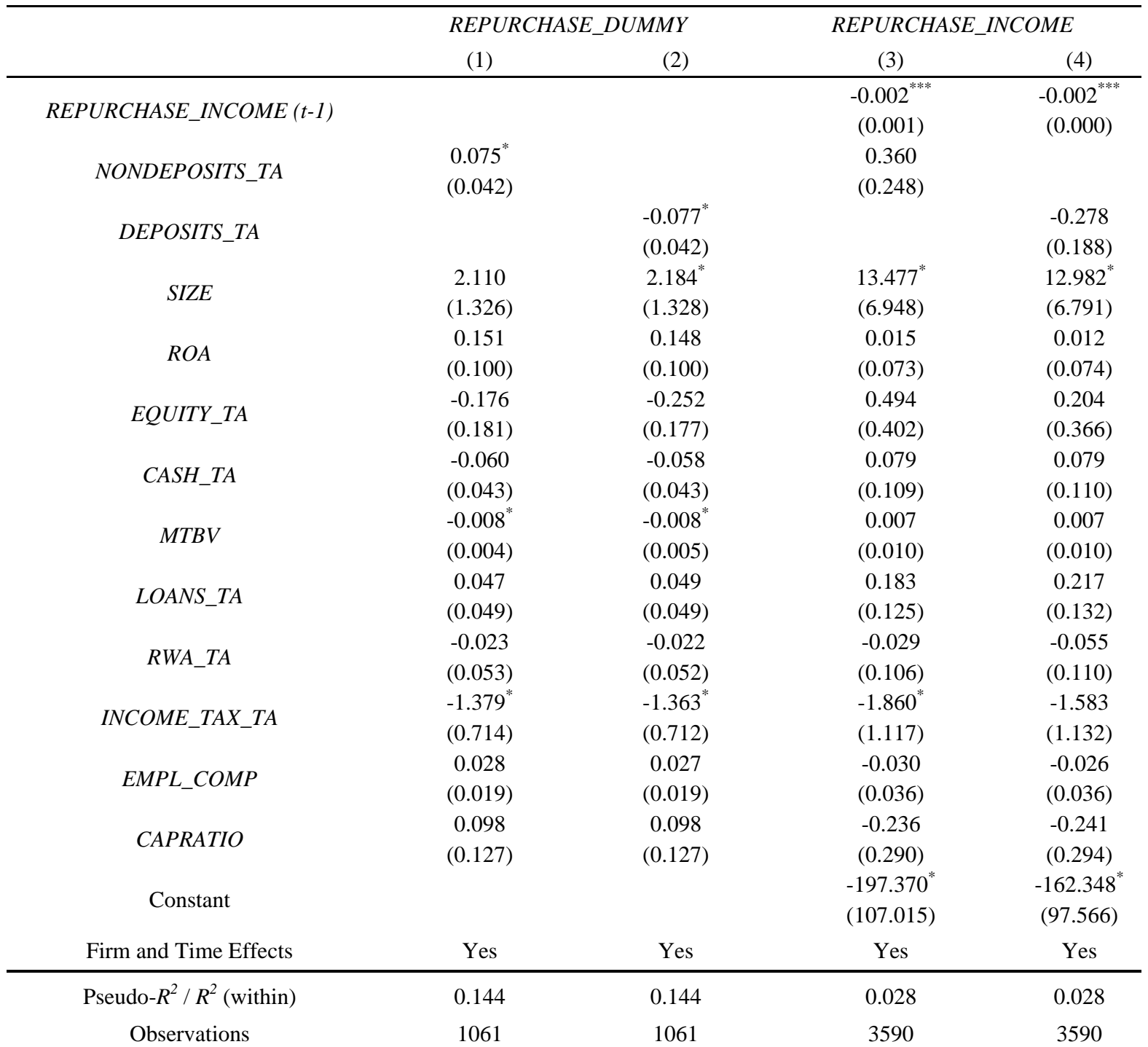

Each column estimates regression models during the sample period 2008q4-2011q3. Columns 1-2: Coefficients estimated by a Logit model for REPURCHASE_DUMMY. The regressors include also a set of dummies for banks and quarters (not reported). Standard errors are reported in parentheses. Columns 3-4: Coefficients estimated by an Ordinary Least Squares (OLS) model for REPURCHASE_INCOME. The regressors include also a set of dummies for banks and quarters (not reported). REPURCHASE_INCOME is winsorized at the $1 \%$ and $99 \%$ level. Standard errors are clustered at the bank level and are reported in parentheses. Significance: ${ }^{*} \mathrm{p}<0.10,{ }^{* *} \mathrm{p}<0.05,{ }^{* * * *} \mathrm{p}<0.01$

\section{Conclusion}

The paper analyses a large sample of commercial banks from the United States during 2006-20011, and shows that there is statistically important relationship between the firms' dividends and leverage after the end of 2008. We observe that the impact from leverage on dividends depends from the type of debt that we consider in the estimated specification. The deposit leverage, measured by the deposits-to-assets ratio, has got negative sign on the variable for the probability of paying dividends and on the variables for the dividend payout ratio. Oppositely, the impact from the non-deposit leverage on the same variables is positive. Since dividends can be viewed as shifting risk from equityholders to debtholders, the results suggest that by paying dividends our banks tend to shift the owners' risk on non-deposit creditors, rather than on depositors. This pattern is significant after the end of 2008, while remains not statistically interesting during the previous time period. During the crisis of 2008-2009 banks resorted to funding through deposits in order to obtain the liquidity needed. Simultaneously, with the severe episodes of distress in 
financial markets, depositors started to see their funds at risk. Feared from withdrawals, banks refrained from shifting risk on depositors by distributing dividends to equityholders, and thereby maintained a critical source of liquidity.

The main finding of the paper is that banks' dividends interact with the type of debt instruments used by the same firms. Out of this result, we can draw interesting suggestions for policy making. First, we support those views arguing that the payment of dividends should be restricted for banks experiencing distress (among others, see Brunnermeier et al. (2009), and Goodhart et al. (2010)) (Note 19)

Indeed, our outcomes show that banks which were paying more generous dividends during the latest crisis, were also those firms which had larger shares of non-deposit debt, which is generally seen as a less stable resource of financing than deposits. Secondly, based on our estimated patterns we raise the ultimate question whether there may be an interplay between dividends and the type of instruments which banks use in order to fulfill their regulatory capital standards. In fact, the regulation developed with the Basel Capital Accord allows subordinated debt instruments with at least a five year maturity to be counted as tier 2 capital. This paper has displayed that non-deposit debt moves in the same direction of dividends. If non-deposit debt may restore capital levels but at the same time prompts banks to pay out earnings, then our suggestion to supervisors is to monitor potential inefficiencies arising from the friction between dividends and debt funding.

\section{Acknowledgements}

I am grateful to Gyöngyi Lóránth for insightful discussions and comments. This paper has also greatly benefited from suggestions provided by Rüdiger Fahlenbrach, Alois Geyer, Christian Laux, Alexander Mürmann, Giovanna Nicodano, Loriana Pelizzon, Stefan Pichler, Leopold Sögner, Josef Zechner, and seminar participants at the Vienna Graduate School of Finance. I acknowledge the financial support from the Austrian Science Fund, the UniCredit \& Universities Leopold Gratz Foundation, and the WU Gutmann Center.

\section{References}

Acharya, V.V., Gale, D., \& Yorulmazer, T. (2011). Rollover Risk and Market Freezes. Journal of Finance, 66, 1175-1207.

Acharya, V.V., Gujral, I., Kulkarni, N., \& Shin, Y.S. (2012). Dividends and Bank Capital in the Financial Crisis of 2007-2009. National Bureau of Economic Research Working Paper No. 16896.

Acharya, V.V., Mehran, H., \& Thakor, A. (2010). Caught Between Scylla and Charybdis? Regulating Bank Leverage When There is Rent Seeking and Risk Shifting. Federal Reserve Bank of New York Staff Report No. 469.

Acharya, V.V., \& Mora, N. (2012). Are Banks Passive Liquidity Backstops? Deposit Rates and Flows during the 2007-2009 Crisis. National Bureau of Economic Research Working Paper No. 17838.

Admati, A.R., DeMarzo, P.M., Hellwig, M.F., \& Pfleiderer, P.C. (2013). Fallacies, Irrelevant Facts, and Myths in the Discussion of Capital Regulation: Why Bank Equity is not Socially Expensive. Max Planck Institute for Research on Collective Goods 2013/23.

Adrian, T., \& Shin, H. S. (2011). Financial Intermediary Balance Sheet Management. Federal Reserve Bank of New York Staff Report No. 532.

Akerlof, G., \& Romer, P.M. (1993). Looting: The Economic Underworld of Bankruptcy for Profit. Brookings Papers on Economic Activity, Economic Studies Program, Brookings Institution 24, 1-74.

Allen, F., Bernardo, A., \&Welch, I. (2000). A Theory of Dividends Based on Tax Clientele. Journal of Finance, 55, 2499-2536.

Allen, F., \& Michaely, R. (2003). Payout Policy. In G. Constantinides, M. Harris, and R. Stulz (Eds.), Handbook of Economics of Finance. Elsevier.

Anderson, T.W., \& Rubin, H. (1949). Estimation of the Parameters of a Single Equation in a Complete System of Stochastic Equations. The Annals of Mathematical Statistics, 46-63.

Arellano, M., \& Bond, S. (1991). Some Tests of Specification for Panel Data: Monte Carlo Evidence and an Application to Employment Equations. Review of Economic Studies, 58, 277-297.

Arellano, M., \& Bover, O. (1995). Another Look at the Instrumental Variable Estimation of Error-Components Models. Journal of Econometrics, 68, 29-51.

Barclay, M.J., \& Smith, C.W. (1988). Corporate Payout Policy: Cash Dividends versus Open-Market Repurchases. Journal of Financial Economics, 22, 61-82. 
Basse, T., Reddemann, S., Riegler, J.J., \& Graf Von der Schulenburg, J.M. (2014). Bank Dividend Policy and the Global Financial Crisis: Empirical Evidence from Europe. European Journal of Political Economy, 34, 25-31.

Baum, C.F., Schaffer, M.E., \& Stillman, S. (2007). Enhanced Routines for Instrumental Variables/GMM Estimation and Testing. Stata Journal, 7(4), 465-506.

Beltratti, A., \& Stulz, R.M. (2012). The Credit Crisis Around the Globe: Why Did Some Banks Perform Better?, Journal of Financial Economics, 105, 1-17.

Bens, D.A., Nagar, V., Skinner, D.J., \& Wong, M.H.F. (2003). Employee Stock Options, EPS Dilution, and Stock Repurchases. Journal of Accounting and Economics, 36, 51-90.

Ben-David, I. (2010). Dividend Policy Decisions. In H.K. Baker, and J.R. Nofsinger (Eds.), Behavioral Corporate Finance. John Wiley \& Sons.

Berger, A.N., DeYoung, R., Flannery, M.J., Lee, D., \& Öztekin, Ö. (2008). How Do Large Banking Organizations Manage Their Capital Ratios?. Journal of Financial Services Research, 34, 123-149.

Berrospide, J.M. (2013). Bank Liquidity Hoarding and the Financial Crisis: An Empirical Evaluation. Federal Reserve Board Working Paper.

Bhargava, A. (2010). An Econometric Analysis of Dividends and Share Repurchases by U.S. Firms. Journal of the Royal Statistical Society Series A (Statistics in Society), 173, 631-656.

Bhattacharya, S. (1979). Imperfect Information, Dividend Policy, and the Bird in the Hand Fallacy. Bell Journal of Economics, 10, 259-270.

Biorn, E. (2004). Regression System for Unbalanced Panel Data: A Stepwise Maximum Likelihood Procedure. Journal of Econometrics, 122, 281-91.

Black, F. (1976). The Dividend Puzzle. Journal of Portfolio Management, 2, 5-8.

Blundell, R., \& Bond, S. (1998). Initial Conditions and Moment Restrictions in Dynamic Panel Data Models. Journal of Econometrics, 87, 115-143.

Boldin, R., \& Legget, K. (1995). Bank Dividend Policy as a Signal of Bank Quality. Financial Services Review, 4, $1-8$.

Boyson, N., Helwege, J., \& Jindra, J. (2014). Crises, Liquidity Shocks, and Fire Sales at Commercial Banks. Financial Management, 43, 857-884.

Braggion, F., \& Moore, L. (2010). Dividend Policies in Unregulated Market: The London Stock Exchange 1895-1905. Review of Financial Studies, 24, 2935-2973.

Brennan, M.J., \& Thakor, A.V. (1990). Shareholder Preferences and Dividend Policy. Journal of Finance, 45, 993-1019.

Brockman, P., \& Unlu, E. (2009). Dividend Policy, Creditor Rights, and the Agency Costs of Debt. Journal of Financial Economics, 92, 276-299.

Brunnermeier, M., Crockett, A., Goodhart, C., Persaud, A., \& Shin, H.S. (2009). The Fundamental Principles of Financial Regulation. 11th Geneva Report on the World Economy. Retrieved from http://www.princeton.edu/ markus/research/papers/Geneva11.pdf

Calomiris, C.W. (2012). Getting the Right Mix of Capital and Cash Requirements in Prudential Bank Regulation. Journal of Applied Corporate Finance, 24, 33-41.

Calomiris, C.W., \& Kahn, C.M. (1991). The Role of Demandable Debt in Structuring Optimal Banking Arrangements," The American Economic Review, 81, 497-513.

Casey, K.M., \& Dickens, R.N. (2000). The Effects of Tax and Regulatory Changes on Commercial Bank Dividend Policy. Quarterly Review of Economics and Finance, 40, 279-293.

Datta, S., Iskandar-Datta, M., \& Raman, K. (2005). Managerial Stock Ownership and the Maturity Structure of Corporate Debt. Journal of Finance, 60, 2333-2350.

Demirgüç-Kunt, A., \& Huizinga, H. (2010). Bank Activity and Funding Strategies: The Impact on Risk and Returns. Journal of Financial Economics, 98, 626-650.

Dhrymes P.J., \& Kurz, M. (1967). Investment, Dividend and External Finance Behavior of Firms. In Determinants of Investment Behavior (pp. 427-467). National Bureau of Economic Research, New York: Columbia University Press. 
Diamond, D.W. (1991). Debt Maturity Structure and Liquidity Risk. The Quarterly Journal of Economics, 106, 709-737.

Dickens, R.N., Casey, K.M., \& Newman, J.A. (2002). Bank Dividend Policy: Explanatory Factors. Quarterly Journal of Business and Economics, 41, 3-12.

Easterbrook, F.H. (1984). Two Agency-Cost Explanations of Dividends. American Economic Review, 74, 650-659.

Eriotis, N., Vasiliou, D., \& Zisis, V. (2007). A Bird's Eye View of the Dividend Policy of the Banking Industry in Greece. International Research Journal of Finance and Economics, 11, 21-29.

Fahlenbrach, R., \& Stulz, R.M. (2011). Bank CEO Incentives and the Credit Crisis. Journal of Financial Economics, 99, 11-26.

Fama, E.F. (1974). The Empirical Relationships between the Dividend and Investment Decisions of Firms. American Economic Review, 64, 304-318.

Farre-Mensa, J., Michaely, R., \& Schmalz, M.C. (2014). Payout Policy. Ross School of Business Paper No. 1227.

Feldman, R., \& Schmidt, J. (2001). Increased Use of Uninsured Deposits: Implications for Market Discipline. Federal Reserve Bank Minneapolis Fed Gazette, March 18-19.

Frank, M.Z., \& Goyal, V.K. (2009). Capital Structure Decisions: Which Factors are Reliably Important?. Financial Management, 38, 1-37.

Freixas, X.Z., \& Parigi, B.M. (2008). Banking Regulation and Prompt Corrective Action. CESifo Working Paper No. 2136.

Freixas, X., \& Rochet, J. (2008). Microeconomics of Banking, Second Edition, MIT Press.

Gatev, E., Schuermann, T., \& Strahan, P. (2007). How Do Banks Manage Liquidity Risk? Evidence from the Equity and Deposit Markets in the Fall of 1998. In M. Carey, and R. M. Stulz (Eds.), The Risks of Financial Institutions. University of Chicago Press.

Goldsmith-Pinkham, P., \& Yorulmazer, T. (2010). Liquidity, Bank Runs, and Bailouts: Spillover Effects During the Northern Rock Episode. Journal of Financial Services Research, 37, 83-98.

Goodhart, C., Peiris, M.U., Tsomocos, D.P., \& Vardoulakis, A.P. (2010). On Dividend Restrictions and the Collapse of the Interbank Market. Annals of Finance, 6(4), 455-473.

Gorton, G.B. (2010). Questions and Answers about the Financial Crisis. National Bureau of Economic Research Working Paper No. 15787.

Gorton, G., \& Metrick, A. (2012). Securitized Banking and the Run on Repo. Journal of Financial Economics, 104, 425-451.

Gropp, R., \& Heider, F. (2010). The Determinants of Capital Structure: Some Evidence from Banks. Review of Finance, 14, 587-622.

Grullon, G., \& Ikenberry, D.L. (2000). What Do We Know About Stock Repurchases?. Journal of Applied Corporate Finance, 13, 31-51.

Grullon, G., \& Michaely, R. (2002). The Information Content of Share Repurchase Programs. Cornell University Ithaca NY, Working Paper.

Gupta, M.C., \& Walker, D.A. (1975). Dividend Disbursal Practices in Commercial Banking. Journal of Financial and Quantitative Analysis, 10, 515-529.

Haq, M., \& Heaney, R. (2012). Factors Determining European Bank Risk. Journal of International Financial Markets, Institutions and Money, 22, 696-718.

Harris, M., \& Raviv, A. (1990). Capital Structure and the Informational Role of Debt. Journal of Finance, 45, 321-350.

Harris, M., \& Raviv, A. (1991). The Theory of Capital Structure. Journal of Finance, 46, 297-355.

Heider, F., Hoerova, M., \& Holthausen, C. (2009). Liquidity Hoarding and Interbank Market Spreads: The Role of Counterparty Risk. European Banking Center Discussion Paper.

Heinkel, R. (1982). A Theory of Capital Structure Relevance under Imperfect Information. Journal of Finance, 37, 1141-1150.

Hirtle, B. (1998). Bank Holding Company Capital Ratios and Shareholder Payouts. Current Issues in Economics and Finance 4, Federal Reserve Bank of New York. 
Hirtle, B. (2004). Stock Repurchases and Bank Holding Company Performance. Journal of Financial Intermediation, $13,28-57$.

Hoggarth, G., Mahadeva, L., \& HBC Martin, J. (2010). Understanding International Bank Capital Flows during the Recent Financial Crisis. Bank of England Financial Stability Paper 8.

Holtz-Eakin, D., Newey, W.K., \& Rosen, H.S. (1988). Estimating Vector Autoregressions with Panel Data. Econometrica, 56, 1371-1395.

Honoré, B.E. (1992). Trimmed Lad and Least Squares Estimation of Truncated and Censored Regression Models with Fixed Effects. Econometrica, 60, 533-565.

Huang, R., \&Ratnovski, L. (2009). Why Are Canadian Banks More Resilient?. International Monetary Fund Working Paper No. 09/152.

Jensen, M.C. (1986). Agency Costs of Free Cash Flow, Corporate Finance, and Takeovers. American Economic Review, 76, 323-329.

Jaccard, J, Wan, C.K., \& Turrisi, R. (1990). The Detection and Interpretation of Interaction Effects between Continuous Variables in Multiple Regression. Multivariate Behavioral Research, 25, 467-478.

John, K., \& Williams, J. (1985). Dividends, Dilution, and Taxes: A Signalling Equilibrium. Journal of Finance, 40, 1053-1070.

Kahle, K.M. (2002). When a Buyback isn't a Buyback: Open Market Repurchases and Employee Options. Journal of Financial Economics, 63, 235-261.

Kahle, K.M., \&Stulz, R.M. (2010). Financial Policies and the Financial Crisis: How Important Was the Systemic Credit Contraction for Industrial Corporations?. National Bureau of Economic Research Working Paper No. 16310.

Kanas, A. (2013). Bank Dividends, Risk, and Regulatory Regimes. Journal of Banking and Finance, 37, 1-10.

Kauko, K. (2012). Why is Equity Capital Expensive for Opaque Banks?. Bank of Finland Research Discussion Paper No.4.

Kisgen, D. (2006). Capital Ratings and Capital Structure. Journal of Finance, 61, 1035-1072.

Kleff, V., \& Weber, M. (2010). Aspects of Payout Policy of German Savings Banks. Kredit und Kapital, 43, 39-63.

Leland, H.E., \& Pyle, D.H. (1977). Informational Asymmetries, Financial Structure, and Financial Intermediation. Journal of Finance, 32, 371-387.

Leuz, C., Deller, D., \& Stubenrath, M. (1998). An International Comparison of Accounting-Based Payout Restrictions in the United States, United Kingdom and Germany. Accounting and Business Research, 28, 111-129

Lintner, J. (1956). Distribution of Incomes of Corporations among Dividends, Retained Earnings, and Taxes. American Economic Review, 46, 97-113.

Martel, M., Van Rixtel, A., \& González Mota, E. (2012). Business Models of International Banks in the Wake of the 2007-2009 Global Financial Crisis. Bank of Spain, Revista de Estabilidad Financiera, 22, 99-121.

Martinez Peria, M., \& Schmuckler, S. (2001). Do Depositors Punish Banks for Bad Behavior? Market Discipline, Deposit Insurance and Banking Crises. Journal of Finance, 56, 1029-1051.

McCabe, G.M. (1979). The Empirical Relationship between Investment and Financing: A New Look. Journal of Financial and Quantitative Analysis, 14, 119-135.

Mercado-Méndez, J., \& Willey, T. (1995). Agency Costs in the Banking Industry: An Examination of Ownership Behavior, Leverage and Dividend Policy. Journal of Economics and Finance, 19, 105-117.

Miller, M., \& Rock, K. (1985). Dividend Policy under Asymmetric Information. Journal of Finance, 40, 1031-1051

Mora, N. (2010). Can Banks Provide Liquidity in a Financial Crisis?. Economic Review, Federal Reserve Bank of Kansas City.

Myers, S.C. (1977). Determinants of Corporate Borrowing. Journal of Financial Economics, 5, 147-175.

Myers, S.C., \& Majluf, N. (1984). Corporate Financing and Investment Decisions when Firms Have Information that Investors do not Have. Journal of Financial Economics, 13, 187-221.

Nguyen, M.C. (2010). XTSUR: Stata Module to Estimate Seemingly Unrelated Regression Model on Unbalanced Panel Data. Statistical Software Components No. S456953, Boston College Department of Economics. 
Nickell, S. (1981). Biases in Dynamic Models with Fixed Effects. Econometrica, 1417-1426.

Octavia, M., \& Brown, R. (2010). Determinants of Bank Capital Structure in Developing Countries: Regulatory Capital Requirement versus the Standard Determinants of Capital Structure. Journal of Emerging Markets, 15, 50-62.

Ofer, A.R., \& Thakor, A.V. (1987). A Theory of Stock Price Responses to Alternative Corporate Cash Disbursement Methods: Stock Repurchases and Dividends. Journal of Finance, 42, 365-394.

Onali, E. (2012). Moral Hazard, Dividends and Risk in Banks. Bangor Business School Research Paper 11/012.

Oura, H., González-Hermosillo, B., Chan-Lau, J.A., Gudmundsson, T., \& Valckx, N. (2013). Changes in Bank Funding Patterns and Financial Stability Risks. International Monetary Fund.

Ross, S. (1977). The Determination of Financial Structure: The Incentive Signaling Approach. Bell Journal of Economics, 8, 23-40.

Rozeff, M. (1982). Growth, Beta and Agency Costs as Determinants of Dividend Payout Ratios. Journal of Financial Research, 3, 249-259.

Shin, H.S. (2009). Securitization and Financial Stability. Economic Journal, 119, 309-332.

Smith, C.W., \& Warner, J.B. (1979). On Financial Contracting: An Analysis of Bond Covenants. Journal of Financial Economics, 7, 117-161.

Stock, J.H., \& Yogo, M. (2005). Testing for Weak Instruments in Linear IV Regression. In D.W.K. Andrews, and J.H. Stock (Eds.), Identification and Inference for Econometric Models: Essays in Honor of Thomas Rothenberg. Cambridge University Press.

Van Rixtel, A., \& Gasperini, G. (2013). Financial Crises and Bank Funding: Recent Experience in the Euro Area. Bank for International Settlements (BIS) Working Paper No. 406.

Vázquez, F.F., \& Federico, P. (2012). Bank Funding Structures and Risk: Evidence from the Global Financial Crisis. International Monetary Fund Working Paper No. 12/29.

Wooldridge, J.M. (2010). Econometric analysis of Cross Section and Panel Data, MIT Press.

Zellner, A. (1962). An Efficient Method of Estimating Seemingly Unrelated Regressions and Tests for Aggregation Bias. Journal of the American Statistical Association, 57, 348-368.

Zellner, A. (1963). "Estimators for Seemingly Unrelated Regression Equations: Some Exact Finite Sample Results," Journal of the American Statistical Association, 58, 977-992.

Zellner, A., \& Huang, D.S. (1962). Further Properties of Efficient Estimators for Seemingly Unrelated Regression Equations. International Economic Review, 3, 300-313.

\section{Notes}

Note 1. A standard classification distinguishes between wholesale and retail debt funding. In general, the former includes central bank liquidity, interbank loans, other short-term debt, most notably repurchase agreements (repos) and commercial paper (CP), and longer-term debt. Retail debt funding is essentially funding through customer deposits, such as current, savings and term deposits (Martel, Van Rixtel, and González Mota (2012)). Note that, the measures we employ for the banking leverage are constructed using balance sheet data and do not capture effects from off-balance sheet transactions.

Note 2. SNL Financial LC is a financial information firm headquartered in the United States, which covers more than 50,000 private and public international companies operating in the most relevant market sectors. See http://www.snl.com/.

Note 3. The sample includes operating independent banks and bank holding companies, while acquired or defunct companies are excluded. Focusing on banks which survived across the crisis, we can examine whether the crisis has induced changes in the funding of banks, which ultimately brought the composition of the firms' leverage to play a role on dividends. In the following empirical analysis we split the sample into different time periods (before/after the crisis). By looking at banks which survived across the sub-periods, we can explore whether the troubles in the banks' financing during the turmoil could influence dividends, as compared to the previous more "tranquil" period.

Note 4. SNL Financial reports only positive values for DIVIDEND_EARNINGS and DIVIDEND_EQUITY, in the sense that, the two payout ratios are not computed for banks reporting negative earnings and/or negative equity. The 
banks of our sample which report negative earning are about the $16 \%$ of the total year-quarter observations, while the banks with negative equity are about the $0.53 \%$ of the total year-quarter observations. Notice that, banks with a negative balance in retained earnings, typically can't make dividend payments to shareholders. The only common exception is when companies are dissolving or liquidating and pay dividends out of cash balances (although, defunct companies are not in our sample). Another instance we wish to give mention, is that, some companies may set dividends at the beginning of the year and then pay equal dividends each quarter. However, given that we are computing the dividend payout over earnings and equity (which are not likely to stay the same across quarters), we don't think that this issue may affect the results. We further checked that, the shares of banks which have the same value of DIVIDEND_EARNINGS during two consecutive quarters is less than $1 \%$ of the whole sample.

Note 5. Given that, the standard deviation of DEPOSITS_TA is 9.685, the impact on DIVIDEND_EQUITY is equal to $(9.685) *(-0.045)=43.583 \%$.

Note 6. In the seminal paper of Lintner (1956) dividends follow a partial adjustment model. The coefficient estimated on the lagged dependent payout ratio is informative on the speed of adjustment of dividends towards their target. The main result of Lintner (1956) is that corporations tend to "smooth" their dividends and adjust them towards a long-run target payout level. In our generalized partial adjustment model (2) the speed of adjustment coefficient would be computed as one minus the coefficient estimated on the lagged dependent variable. Given that, the lagged DIVIDEND_EARNINGS and DIVIDEND_EQUITY are negative during the pre-crisis period, the speed of adjustment would be larger than one. This suggests that banks were adjusting their dividends relatively quickly, and we cannot claim that we observe some "stickiness" in dividends as was in Lintner (1956).

Note 7. Some of the control variables have coefficients on the two payouts of high magnitude and opposite sign. This might be due to the construction of those controls. ROA is negative on DIVIDEND_EARNINGS, while positive on DIVIDEND_EQUITY. The firm's earnings are at the denominator in DIVIDEND_EARNINGS, while at the numerator in ROA. EQUITY_TA is negative on DIVIDEND_EQUITY, while positive on DIVIDEND_EARNINGS. The firm's equity is at the numerator of EQUITY_TA, while at the denumerator in DIVIDEND_EQUITY.

Note 8. Martel, Van Rixtel, and González Mota (2012) note that, the five United States investment banks which existed before the crisis - Goldman Sachs, Morgan Stanley, Merrill Lynch, Lehman Brothers and Bear Stearns - did not have deposit taking business. However, in October 2008 Goldman Sachs and Morgan Stanley changed their official status from investment bank to traditional bank holding companies.

Note 9. Signalling models for dividends have been developed, among others, by Bhattacharya (1979), Miller and Rock (1985), and John and Williams (1985). The issuance of debt can signal the bank quality in the studies of, among others, Ross (1977), Leland and Pyle (1977), Heinkel (1982), Myers and Majluf (1984), and Harris and Raviv (1991).

Note 10. Jensen (1986) explains how debt can substitute dividends in reducing agency costs due to free cash flows.

Note 11. SNL Financial provides data on insider ownership only for the last date of observation, hence we implicitly assume that our firms did not change significantly their governance structure during 2008q4-2011q3.

Note 12. Martinez Peria and Schmuckler (2001) claim that, deposit insurance is not always fully credible, and does not decrease market discipline, especially during crises. Both insured and uninsured deposits can be sensitive to banks' risk-taking.

Note 13. According to Diamond (1991), Datta, Iskandar-Datta, and Raman (2005), and Kisgen (2006), short-term debt is a stronger monitoring device than long-term.

Note 14. We consider the list from the Financial Stability Board dated November 4, 2011. Among the 29 worldwide banks defined as "systemically important financial institutions" we select the following United States institutions: Bank of America, Bank of New York Mellon, Citigroup, Goldman Sachs, JPMorgan Chase, Morgan Stanley, State Street, and Wells Fargo.

Note 15. We follow the approach for fitting so-called seemingly-unrelated regression (SUR) models developed with Zellner (1962). The estimation is performed according to the one-way random effect estimation of seemingly-unrelated regressions implemented by Nguyen (2010). We also check that results are similar if we estimate the systems according to the approach from Biorn (2004) for the estimation of seemingly-unrelated regressions in unbalanced panel data sets. Similar systems of simultaneous equations are estimated using, alternatively, DIVIDEND_EARNINGS and DIVIDEND_DUMMY as dependent variables for the dividend equation. These results are not reported in the paper for not overloading the results. However, we have verified that these latter 
not-reported outcomes are of the same quality to the outcomes of Table 13 in what concerns sign and statistical significance of the leverage variable in the dividend equation.

Note 16. The IV estimation performs better on DIVIDEND_EQUITY than on DIVIDEND_EARNINGS. Looking at the model for DIVIDEND_EQUITY, in the first-stage regression the Anderson-Rubin test rejects the null hypothesis that the coefficient of DEPOSITS_AS in the structural equation is zero (see Anderson-Rubin (1949)). In the second stage regression, the Stock and Yogo test verifies whether our instrument is weak (see Stock and Yogo (2005)). The test is based on the $F$ statistic of the Cragg-Donald statistic. The null hypothesis is that the estimator is weakly identified, in the sense that it is subject to bias that the investigator finds unacceptably large. To reject the null, the Cragg-Donald $F$ statistic must exceed the critical values tabulated by Stock and Yogo (2005). According to the Stock and Yogo test our equation for DIVIDEND_EQUITY would not to be weakly identified. For example, if we are willing to accept a rejection rate of at most $10 \%$, then we reject the null of weak identification, because the Cragg-Donald $F$ statistic is above the critical value equal to 16.38 .

Note 17. These results - for brevity - are not reported.

Note 18. Although omitted for brevity, we have inspected the behavior of repurchases during quarters. The highest values of REPURCHASE_INCOME are observed during 2007q2 and 2007q3, when REPURCHASE_INCOME is always above $20 \%$. This trend is similar to the shares repurchased by United States industrial firms examined by Kahle and Stulz (2010). In their sample, the ratio of repurchases over assets peaks during the third quarter of 2007, while falls during the first quarter of 2009, which coincide with the highs and the lows of the stock market.

Note 19. Other articles arguing that dividends should be limited when banks experience financial troubles include Acharya et al. (2012), and Admati et al.(2013). For further comments in the framework of the debate around sanctions on dividends, we refer to Scharfstein and Stein (2008, "This Bailout Doesn't Pay Dividends," The New York Times, October 20; Wessel, D., 2008, "Brainstorming about Bailouts" Wall Street Journal, March 13), and to Rosengren (2010, "Dividend Policy and Capital Retention: A Systemic "First Response," speech delivered at the Rethinking Central Banking conference, Washington DC, October 10, available at http://www.bos.frb.org/news/speeches/rosengren/2010/101010/101010.pdf).

\section{Appendix}

We report below the definition of the variables employed in the empirical analysis, including the variables' "KeyFields" identified by SNL Financial.

CAPRATIO [SNL KeyField: 131990]: Risk-weighted Capital Ratio

CASH_TA: Cash and cash equivalents [SNL KeyField: 131920] as a percent of total assets [SNL KeyField: 131929]

CURRENTACC_TA: Current Accounts [SNL KeyField: 132471] as a percent of total assets [SNL KeyField: 131929]

DEPOSITS_TA: Total deposits from customers [SNL KeyField: 132480] as a percent of total assets [SNL KeyField: 131929]

DEP\&NONDEP_TA: Total deposits from customers [SNL KeyField: 132480] plus total debt [SNL KeyField: 131935] as a percent of total assets [SNL KeyField: 131929]

DIVIDEND_DUMMY: Dummy variable assuming value one if the company has got a positive value of regular dividends paid [SNL KeyField: 132933], while zero if the same field is equal to zero

DIVIDEND_EARNINGS [SNL KeyField: 131981]: Dividend payout ratio. Dividends declared per common share during the period as a percent of earnings per share

DIVIDEND_EQUITY [SNL KeyField: 132911]: Dividend/Average Book Value. Dividends declared per common share during the period as a percent of average common equity per share

EMPL_COMP [SNL KeyField: 133387]: Compensation/Average employees. Employee compensation and benefits as a multiple of average full-time-equivalent employees. Compensation and benefits include salaries, wages, bonuses, commissions, changes in reserve for future stock option expense, and other employee benefit costs, also related to employment or retirement benefits, whether paid or deferred, recognized during the period. If the company does not report the average full-time equivalent employees for the period, this is calculated by SNL Financial

EQUITY_TA: Total equity [SNL KeyField: 131939] as a percent of total assets [SNL KeyField: 131929]

FOREIGNDEP_TA: Foreign Deposits [SNL KeyField: 132478] as a percent of total assets [SNL KeyField: 131929] 
INCOME_TAX_TA: Income taxes paid [SNL KeyField: 132981] as a percent of total assets [SNL KeyField: 131929]

INTEREST_DEPOSITS: Interest incurred on deposits as a percent of average deposits

[SNL KeyField: 133831]

JUMBOTIMEDEP_TA: Jumbo time deposits [SNL KeyField: 132476] as a percent of total assets [SNL KeyField: 131929]

LOANS_TA: Net loans to customers [SNL KeyField: 131923] as a percent of total assets [SNL KeyField: 131929]

LOW_INSIDER_DUMMY: Dummy variable assuming value of one in correspondence of a firm insider ownership [SNL KeyField: 221550] lower or equal than $18.231 \%$

MONEYMKTACC_TA: Principal amounts in money-market accounts in domestic offices [SNL KeyField: 132472] as a percent of total assets [SNL KeyField: 131929]

MTBV [SNL KeyField: 132027]: Price/Book. Price as a percent of book value per share. Book value is calculated using financial period end common equity and common shares outstanding values

NONDEPOSITS_TA: Total debt [SNL KeyField: 131935] as a percent of total assets [SNL KeyField: 131929]

NONDEPOSITS_TL: Total debt [SNL KeyField: 131935] divided by the sum of Total Debt [SNL KeyField: 131935] plus Total Deposits from Customers [SNL KeyField: 132480]

OTHERDEP_TA: Other Deposits [SNL KeyField: 243741] as a percent of total assets [SNL KeyField: 131929]

REPOS_TA: Securities that are sold under a corresponding agreement that those securities will be repurchased by the original holder on a specified future date and at an agreed-upon price [SNL KeyField: 132309]

REPURCHASE_INCOME: Common stock repurchased [SNL KeyField: 133872] as a percent of net income after taxes [SNL KeyField: 142046]. The common stock repurchased is as-reported from the cash flow statement for the period. It includes fractional and dissenting shares redeemed on the cash flow statement. This should include all purchases of company stock for treasury stock, compensation plans, recognition and retention plans and acquisitions of common stock by Employee Stock Ownership Plan (ESOP)

REPURCHASE_DUMMY: Dummy variable assuming value one if the company has got a positive value on shares repurchased [SNL KeyField: 133870] while zero if the same field is equal to zero.

RETAILTIMEDEP_TA: Retail Time Deposits [SNL KeyField: 132475] as a percent of total assets [SNL KeyField: 131929]

ROA [SNL KeyField: 132004]: ROAA. Return on average assets; net profit as a percent of average assets

RWA_TA [SNL KeyField: 226936]: Risk-weighted assets/assets. Risk-weighted assets as a percent of assets

SAVINGACC_TA: Principal amounts in non money-market savings accounts in U.S. offices [SNL KeyField: 132473] as a percent of total assets [SNL KeyField: 131929]

SHORTTERM_NONDEP_TA: Borrowings with a maturity of one year or less, not already included in repurchase agreements, notes payable, or subordinated debt [SNL KeyField: 233865]

SIZE: Natural logarithm of total assets [SNL KeyField: 131929]

TARPEQUITY_DUMMY Dummy variable assuming value one if the company has got a positive value of TARP Preferred Equity [SNL KeyField: 218432], while zero if the same field is equal to zero

TARPEQUITY_TA: TARP preferred equity [SNL KeyField: 218432] as a percent of total assets [SNL KeyField: 131929]

TOOBIGTF_DUMMY: Dummy variable assuming value of one in correspondence of "too-big-to-fail" institutions (classified according to the Financial Stability Board, November 2011)

TOTALTIMEDEP_TA: Total time deposits [SNL KeyField: 132477] as a percent of total assets [SNL KeyField: 131929] 